\title{
Review
}

\section{Pyrometallurgical Removal of Zinc from Basic Oxygen Steelmaking Dust - A Review of Best Available Technology}

Daniel J. C. Stewart ${ }^{\mathrm{a}}$, Andrew R. Barron ${ }^{\mathrm{a}, \mathrm{b}, \mathrm{c} *}$

${ }^{a}$ Energy Safety Research Institute, Swansea University Bay Campus, Swansea, SA1 8EN, UK

${ }^{b}$ Department of Chemistry, Rice University, Houston, Texas 77005, USA

${ }^{c}$ Department of Materials Science and Nanoengineering, Rice University, Houston, Texas 77005, USA

KEYWORDS: basic oxygen steelmaking; dust; iron; pyrometallurgy; zinc

\begin{abstract}
Approximately $20 \mathrm{~kg}$ of dust and sludges are produced per ton of liquid steel produced via the blast furnaces $(\mathrm{BF}) /$ basic oxygen furnace $(\mathrm{BOF})$ production route. Many of these dusts are recycled through the sinter plant or blast furnace route without issue, but high zinc content dusts are routinely landfilled. Hydrometallurgical techniques, such as alkaline leaching, that are often utilized to remove zinc from electric arc furnace dusts are inappropriate for recovery of material from BOS dust due to the lower zinc concentration present and extra post-processing steps to utilize the separated iron product. Pyrometallurgical treatment through a rotary hearth furnace (RHF), in processes such as FASTMET ${ }^{\circledR}$, can currently be considered as the most commercially attractive option for the processing and recovery of iron and zinc units when employed as part of an integrated steelworks. The crude zinc oxide produced is suitable for sale to zinc smelters, and the direct reduced iron produced provides process benefits through use, such as reduced blast furnace coking rates and increased productivity. The advantages and disadvantages of variations and alternatives are reviewed with regard to future developments.
\end{abstract}




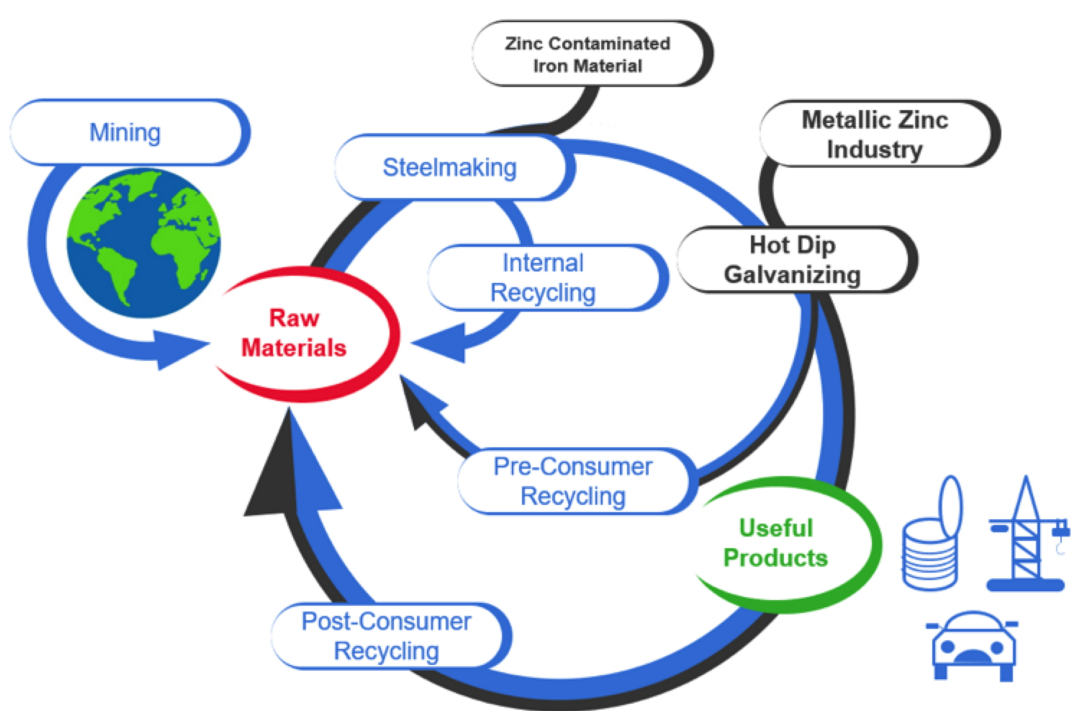

\section{Introduction}

An integrated steelworks, consisting of blast furnaces and a basic oxygen steelmaking facility, is an example of effective materials efficiency in $21^{\text {st }}$ century manufacturing. The most common process for the production of steel is the basic oxygen steelmaking (BOS) process, accounting for well over a billion tons of steel produced globally (World Steel Association). A significant volume of BOS dust is created as a by-product of the production of liquid steel through the BOS process, which is generally recovered through the off-gas cleaning system. BOS dust is also known as basic oxygen furnace (BOF) dust, BOF fume, or BOS slurry, and varies depending on the origin of the material. For simplicity, this paper defines BOS dust as the fine ferrous by-product produced during the blowing period in an oxygen converter/furnace at a steelmaking facility, which is wet-scrubbed from the off-gas system of the steelmaking plant and will refer to the material as such when citing references using differing nomenclature.

Typically, BOS dust is highly metalized and has iron content $\left(>60 \% \mathrm{Fe}_{\mathrm{Tot}}\right)$ comparable with good quality ores, and therefore could be a valuable secondary source of iron units for an integrated steel plant. While the recirculation of fine iron-bearing materials back into the blast furnace is commonplace, when these materials are contaminated with zinc, the typical process 
routes become unsuitable. Because the blast furnace process is remarkably sensitive to volatile metals most critically zinc these, zinc-containing materials have been ordinarily disposed of through landfill. The reason for the sensitivity to zinc is that once charged into a blast furnace, any zinc component is reduced to elemental $\mathrm{Zn}$. Due to the low boiling point of the metal (907 $\left.{ }^{\circ} \mathrm{C}\right)$ compared to the furnace temperature range $\left(1600-1650{ }^{\circ} \mathrm{C}\right)$, the vapor rises back through the furnace stack and re-condenses (Singh 2012), leading to condensation of scaffolds (accretions) of zinc on the walls of the furnace. These deposits can affect both solid and gas flow through the furnace negatively impacting productivity and risking damage to the furnace lining through burden slips. Zinc is also known to attack refractories in the upper stack of the furnace and therefore potentially impact on campaign life (Narita 1981). As such, the concentration of zinc loaded to a blast furnace is tightly controlled, with levels around 100-120 g/THM generally permissible (THM = tons of hot metal). In context, for a plant producing 10 Mt of liquid steel per annum, this would allow for a maximum $1 \mathrm{kt}$ of zinc to be charged to the furnace per annum if these limits are to be followed. The dilution of zinc bearing wastes and reintegrating them into existing steelmaking processes are therefore not suitable for processing zinc-bearing wastes on a sustainable scale. The volume of zinc re-entering the steelmaking process through galvanized scrap steel recycling is simply too much.

Zinc and iron are routinely married together through the hot-dip galvanization process, with the zinc providing galvanic protection for the steel. It has been postulated that without substantial improvements to the recovery rate of zinc from its industrial uses (principally hotdip galvanizing) global zinc reserves will be outstripped by demand as early as 2050 (Daigo 2014). It is therefore clear, that without a go-between process to economically remove zinc from the steel material cycle, the process of hot dip galvanizing will be dependent on depleting global reserves of zinc. A number of hydrometallurgical techniques, such as alkaline leaching, are often utilized to remove zinc from electric arc furnace dusts (Lin 2017; Shawabkeh 2014; Dutra 2006); however, these are inappropriate for recovery of material from BOS dust due to the lower zinc concentration present, in the latter, and extra post-processing steps to utilize the separated iron product. Nevertheless, ammoniacal leaching has been reported to have results for wastes from BOS furnaces where the zinc content is $2.82 \%$ (Gargul 2015). 
There are several emerging novel techniques for the pyrometallurgical separation of zinc from steelmaking dusts, with one of the most promising being rapid microwave carbothermal reduction (Sun, 2008) which has advantages such as rapid reaction times $(99.99 \%$ $\mathrm{Zn}$ removal in 15 minutes at $1100 \mathrm{~W}$ ) and feasible capture of a metallic zinc product. Hybridized pyrometallurgical/hydrometallurgical techniques have also been studied such as chlorination roasting followed by a leaching step (Jaafer, 2014). These have advantages in the lower processing temperatures required $\left(750^{\circ} \mathrm{C}\right)$ and hence lower energy input when compared to other pyrometallurgical techniques. However, the disadvantages of a poorly valorized ferrous product and comparatively low Zn removal (97\%) mean upscale is unlikely. These technologies are still in their infancy, having not achieved pilot scale operation as of the time of writing, and as such will not form the main basis of this review - instead focusing more on proven scalable technology and how they might be applied to process BOS dust.

The need to adopt commercial routes to the re-use of zinc waste from BOS dust is part of a broader move to lower the environmental impact of the steel industry (Allwood 2010; Kim \& Worrell 2002) and ensure its economic sustainability (Fisher 2019; Lobato 2015). Thus, there are significant incentives to find ways to as much waste as possible. Herein, we review approaches to the re-use of BOS dust, with particular focus on those that provide the best available technology to supplement an integrated steelworks in processing its zinc-bearing byproducts, and to make recommendations to the industry based off viability, technical feasibility and environmental considerations. The goal is to ensure that BOS dust is considered a material with potential as resource rather than a waste.

The objective of this paper is to provide a short to medium term outlook for the feasibility of pyrometallurgical separation techniques for BOS dusts. The recycling of low zinc bearing materials is routinely performed at most steel plants through dilution in the blast furnace burden. Very high Zn bearing materials such as Electric Arc Furnace dusts are very well studied and reviewed (Lin 2017; Walburga Keglevich de Buzin 2017) due to the hazardous nature of the material. Materials that are moderately contaminated with $\mathrm{Zn}$ such as BOS dust are comparatively understudied, despite the fact they are produced on a far greater scale. 


\section{The basic oxygen steelmaking (BOS) process}

Basic oxygen steelmaking is the most common production route for steel in the world today (Fig. 1). Immediately following WWII, it became commercially viable to mass produce huge volumes of high purity oxygen for industrial use. This availability of oxygen for use as an oxidizing agent in the steel industry rapidly supplanted the outdated Open-Hearth Furnace, as BOS plants are more productive and require no external heat input due to the extremely exothermic nature of the chemical process. In the BOS process, molten pig iron is charged into a converter lined with basic refractory bricks, with scrap steel typically used as an additional iron source and coolant which can make up $25 \%$ by mass of the charge (Singh, 2012). Oxygen is then blown into the vessel at supersonic speeds (Brandt and Warner, 2005) through a watercooled lance to oxidize impurities within the molten iron, which are then trapped in the molten slag or emitted from the vessel as a gas.

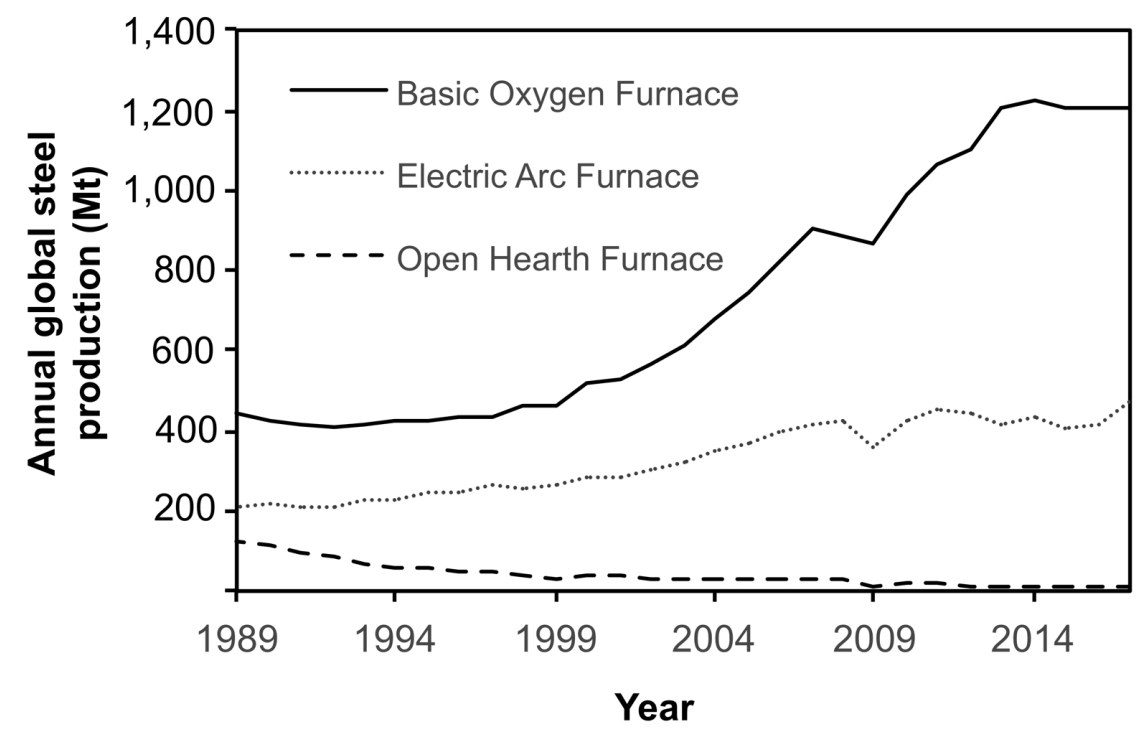

Fig. 1. Global Steel production by process route over the past 30 years. Data adapted from the World Steel Association annual production statistics (World Steel Association 2017).

The chemical reactions within the basic oxygen steelmaking process are given in Eq. 18 , where the state of the reagents is signified by the choice of braces, " \{\} ", to denote a gas phase reactant/product, square brackets, “[ ]", to denote the reactant/product is dissolved in the bulk $\mathrm{Fe}(\mathrm{l})$ phase, and round brackets, “( )", denote the reactant/product is dissolved within the liquid 
slag phase (Mazumadar 2010). The oxygen injected by the lance dissociates into the molten iron bath (Eq. 1), which then acts to rapidly oxidize impurities within the melt such as $\mathrm{C}, \mathrm{S}, \mathrm{Si}$, $\mathrm{Mn}$ and $\mathrm{P}$ which are either captured into the molten slag or escape the bath as gas in the case of carbon. Fluxes such as $\mathrm{CaO}$ are also added as a processing aid, to promote the removal of $\mathrm{S}$ and $\mathrm{P}$ from the liquid iron. These equations are an oversimplification of the complex equilibria between the slag and metal interfaces but are useful nonetheless to describe the overall sequestration of unwanted elements in the hot metal to the slag or to the gas phase.

$$
\begin{aligned}
& \left\{\mathrm{O}_{2}\right\} \rightarrow 2[\mathrm{O}] \\
& {[\mathrm{C}]+[\mathrm{O}] \rightarrow\{\mathrm{CO}\}} \\
& {[\mathrm{Si}]+2[\mathrm{O}] \rightarrow\left(\mathrm{SiO}_{2}\right)} \\
& 2(\mathrm{CaO})+\left(\mathrm{SiO}_{2}\right) \rightarrow\left(2 \mathrm{CaO} \cdot \mathrm{SiO}_{2}\right) \\
& {[\mathrm{Mn}]+[\mathrm{O}] \rightarrow(\mathrm{MnO})} \\
& 2[\mathrm{P}]+5[\mathrm{O}]+3(\mathrm{CaO}) \rightarrow\left(\mathrm{Ca}_{3}\left(\mathrm{PO}_{4}\right)_{2}\right) \\
& {[\mathrm{FeS}]+(\mathrm{CaO}) \rightarrow(\mathrm{FeO})+(\mathrm{CaS})} \\
& 2[\mathrm{P}]+5(\mathrm{FeO})+4(\mathrm{CaO}) \rightarrow 4\left(\mathrm{CaO}_{2} \mathrm{P}_{2} \mathrm{O}_{5}\right)+5[\mathrm{Fe}]
\end{aligned}
$$

\section{BOS dust}

The BOS process naturally generates co-products alongside the desired liquid steel, and while the largest by mass of these co-products is steelmaking slag (Fisher 2019), the volume of ferrous dusts cannot be ignored. As a consequence of the injection of oxygen into the melt at ultrasonic speeds as well as the turbulent conditions of the bath caused by so-called 'carbon boil', a significant amount of fine material is ejected from the bath. This fine material is then scrubbed out of the off-gas from the process through either wet venturi scrubber systems (Onnen 1972) or dry electrostatic precipitators (Henschen 1968) before the off-gas is suitable to either collect for caloric recovery or to flare to the atmosphere. The BOS dust is then collected either as a filter baghouse dust or a wet filter cake.

\subsection{Formation mechanisms of basic oxygen steelmaking dust}


The mechanisms of formation of BOS dust have been well researched, as the conditions within the furnace and off-gas system can have a significant effect on the chemistry of the dust product. In 1944 Kohlmeyer and Spandau theorized that the reaction of gaseous carbon monoxide formed from partial carbon oxidation was reacting with elemental iron to yield iron pentacarbonyl, i.e., Eq. 9 (Kohlmeyer and Spandau 1944).

$\mathrm{Fe}^{0}+5 \mathrm{CO} \rightarrow \mathrm{Fe}(\mathrm{CO})_{5}$

Since $\mathrm{Fe}(\mathrm{CO})_{5}$ decomposes readily back to $\mathrm{Fe}^{0}$ at comparatively low temperatures $\left(426{ }^{\circ} \mathrm{C}\right)$ (Santos 1983), and therefore it's unlikely that it would be able to form in the steelmaking environment at a temperature in excess of $1500^{\circ} \mathrm{C}$. It would also be expected that performing a blow using carbon monoxide would also cause the characteristic visible fuming associated with the formation of BOS dust, but in practice, this does not occur (Turkdogan 1959). In reality, there are two competing mechanisms at play in the formation of BOS dust, and these are the vaporization or fuming mechanism, and the bubble burst mechanism (Nedar 1996).

Initially the vaporization of iron from a steel bath seems rather counterintuitive because the standard boiling point of iron is $2861{ }^{\circ} \mathrm{C}$ and the temperatures in oxygen steelmaking are around $1000{ }^{\circ} \mathrm{C}$ lower. Nevertheless, Goetz described the phenomenon of localized 'hot spotting' within the BOS process (Goetz 1980), where the extremely exothermic reactions at the gas/metal interface generate heat so rapidly that it cannot be transported away effectively by convection into the bulk of the bath. Temperatures between $2400-2600{ }^{\circ} \mathrm{C}$, as measured on industrial basic oxygen furnaces using optical pyrometry, have been reported. This localized hotspot formation leads to volatilization and oxidation of iron from the bath in the form of a fine fume.

The second mechanism is the mechanical ejection of metal droplets from the bath due to the collapse of $\mathrm{CO}$ bubbles formed in situ (Eq. 2). This reaction spontaneously forms bubbles of carbon monoxide within the steel bath and is critical to the speed of the BOS process, since it provides excellent bath agitation and mixing. Once these bubbles have formed in the extremely high temperatures found in the molten iron, they are forced upwards due to their 
relative density before reaching the surface (Fig. 2a). Upon reaching the surface of the hot metal, the top of the bubble thins (Fig. 2b) until it's surface tension can no longer contain the hot gas, which break clear of the liquid and escapes to atmosphere (Fig. 2c). The resulting high pressure at the edges of the now ruptured bubble (Fig. 2d) form a jet (Fig. 2e) that ejects droplets of molten iron free of the melt (Fig. 2f).

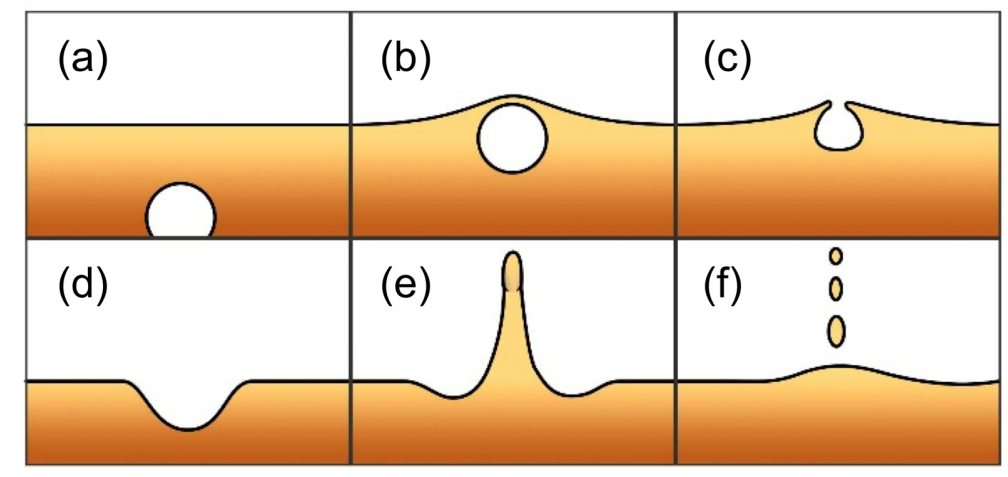

Fig. 2. Schematic of the bubble bursting mechanism for the formation of BOS dust, showing (a) a $\mathrm{CO}$ bubble formed in the hot metal, (b) reaching the surface it thins, (c) breaking clear of the liquid and escaping to atmosphere, where (d) the resulting high pressure at the edges forms a jet (e) that ejects droplets of molten iron free of the melt (f).

From investigations into these two mechanisms it abundantly clear that there is a relationship between the carbon content of the iron bath and the volume of fumes generated. It has been shown in lab scale (Turkdogan 1959; Hoskins 1966) and full production scale at the steel plant in Port Talbot, UK (Steer 2014) that at higher carbon concentrations within the iron bath, the rate of fume generation is higher. However, both mechanisms can be dependent on the carbon levels so this alone is not enough to determine the predominance of each mechanism.

Tsujino et al. devised a method of determining the ratio of so-called 'bubble burst' particles to 'fume' particles to elucidate the dominant production mechanism (Tsujino 1989). Molybdenum and manganese are both typical alloying elements that may be found as part of the melt in a BOS converter, but have significantly different boiling temperatures, $4612{ }^{\circ} \mathrm{C}$ and $1962{ }^{\circ} \mathrm{C}$, respectively. By assuming molybdenum volatilization from the bath is negligible it can be assumed that any molybdenum present within the BOS dust must have been 
mechanically ejected from the bath via the bubble bursting mechanism rather than volatilized, while the manganese concentration would indicate volatilization. This approach allowed for direct measurement of the ratio of the two particle types throughout the blow and showed that the initial dust produced in the blow was principally through the bubble bursting mechanism, whereas at the conclusion of the blowing period the fuming/vaporization mechanism dominated.

It should be note that the volumes of dust generated from BOS converters are widely variable, usually estimated at around 15-20 kg/THM. There is clearly many dependent process variables that can affect the composition of BOS dust, including: lance height, oxygen injection pressure, and slag volume (Okhotskii 2007; Gritzan 2001).

\subsection{The origin of zinc in the BOS process}

The use of galvanized strip steel has increasingly found use in automotive body panels, due to its formability, corrosion resistance and good strength/mass ratio. Steel is the most widely recycled material on the planet (World Steel Association 2017) by mass and in order for steelmaking to be truly sustainable, galvanized steel must also be recycled at the end of its useful service life. Should any galvanized steel be included in the scrap charge to the BOS furnace at the beginning of the process, any zinc present will volatilize almost completely from the blast furnace, upon addition of the pig iron.

Scraps with high zinc content are often cheaper than low zinc content scrap for this reason. Electric arc furnace (EAF) dusts are substantially higher in zinc content, along with other tramp elements such as lead, due to their nature of having typically $100 \%$ scrap charges, (Oustadakis 2010). Integrated plants generally manage BOS dust recycling through careful management of scrap chemistry inputted to the furnace, then reintroducing the material to the sinter plant and then the blast furnace but extremely tight limitations on zinc input mean unexpectedly high zinc material cannot be processed in this manner.

\subsection{Off-gas system design}


One key design feature of a BOS plant's off-gas system, that can have a substantial effect on the chemistry of the dust product, is whether it is a closed or open hood design. In a closed hood system, air ingress into the off-gas system is extremely limited and as such degree of oxidation as well as the formation of some spinel phases are suppressed. This is typical for a steel plant with an off-gas recovery system in place, as the gaseous product of the BOS process has substantial caloric value and is utilized as an energy source. BOS dust from these systems typically has a black appearance. In an open hood system, the opposite occurs, the environment of the system is much more oxidative and combustive. As such higher iron oxides are expected and the off-gas dust has a more reddish appearance (Goetz 1980).

\section{Characterization of BOS dust}

As a potentially valuable ferrous resource, BOS dust from steel plants all around the world has been characterized using a number of different techniques. Although many different monikers are used to describe the material, it is defined in this work as the fine material that is removed from the off-gas system from a BOS vessel, produced during the blowing period.

\subsection{Particle size}

It has been reported that the distribution of particle size within BOS dust samples is from 0.5 $\mu \mathrm{m}$ up to around $50 \mu \mathrm{m}$ as determined by laser-based granulometry. Dividing the dust into a fine $(<38 \mu \mathrm{m})$ and coarse $(>38 \mu \mathrm{m})$ fraction, it was also found that the finer fraction was considerably more Zn rich (Kelebek 2004). Gritzan and Neuschütz subdivided BOS dust into four classifications by size fraction with maxima at $1,12,50$ and $140 \mu \mathrm{m}$, with the largest fraction likely extending past the detection limit of the granulometry technique used $(200 \mu \mathrm{m})$ (Gritzan and Neuschütz 2001). However, it was also found through SEM observations that many of these larger particles were agglomerations of the finer particles (Gargul 2016). Along with the fine and agglomerated particles, the spheres of iron ejected from the melt were also found to be present around $50 \mu \mathrm{m}$ (Gargul 2016). A study on BOS dust particle size distribution between two different, unnamed integrated steelworks in the USA showed differences in the main fractions of the dust, with one plant having a substantially larger fine fraction $<75 \mu \mathrm{m}$ 
than the other (Ma 2016). An investigation on BOS dust produced through the Port Talbot works (UK) showed variation in the particle size analysis throughout the blowing process (Heinrich 2015). A greater proportion of finer particles were generated during the blow than before or after. These findings were also in agreement with that of Kelebek that showed the finer fraction of BOS dust contained a higher proportion of zinc than the coarser fractions (Kelebek 2004). The implication of this observation combined with SEM measurements observations sheds some light on the interaction of the ferrous material with the zinc vapor present immediately above the BOS vessel.

These observations of $\mathrm{Zn}$ enrichment of the finer fraction and zinc being present on the outer surface implies that the iron morphology is dictated by the mechanisms while zinc is still in the gas phase (see above). Once the gas stream has cooled sufficiently, Zn condenses onto the surface of the material as $\mathrm{ZnO}$ and then potentially goes on to react to form $\mathrm{ZnFe}_{2} \mathrm{O}_{4}$ at the $\mathrm{Fe} / \mathrm{Zn}$ interface if the conditions are suitable.

\subsection{Morphology}

Kelebek et al. described the morphology of BOS dust, from scanning electron microscopy (SEM), as comprising a very heterogeneous mixture of particles (Kelebek 2004), with sizes ranging from $3 \mu \mathrm{m}$ to $100 \mu \mathrm{m}$ (Fig. 3a). Many of the finer particles are agglomerated to larger particles, differentiated as spheroidal and non-spheroidal (Fig. 3b). Energy dispersive X-ray spectroscopy (EDS) showed a relatively uniform distribution of zinc across these particles. This information was used to determine that the $\mathrm{Zn}$ in BOS dust is localized almost entirely as a coating around an iron core. This observation was confirmed through a cross-sectional analysis of a particle, showing a metallic iron core, surrounded by iron oxides and zinc oxide/zinc ferrite mixtures (Fig. 3c). These observations were confirmed by other researchers (Vereš 2015), and are in agreement with the observations of two separate and distinct mechanisms of formation: finer more oxidized particles produced through volatilization of iron and much larger, highly metalized and globular particles generated from the solidification of liquid iron droplets ejected via the bubble burst mechanism. 

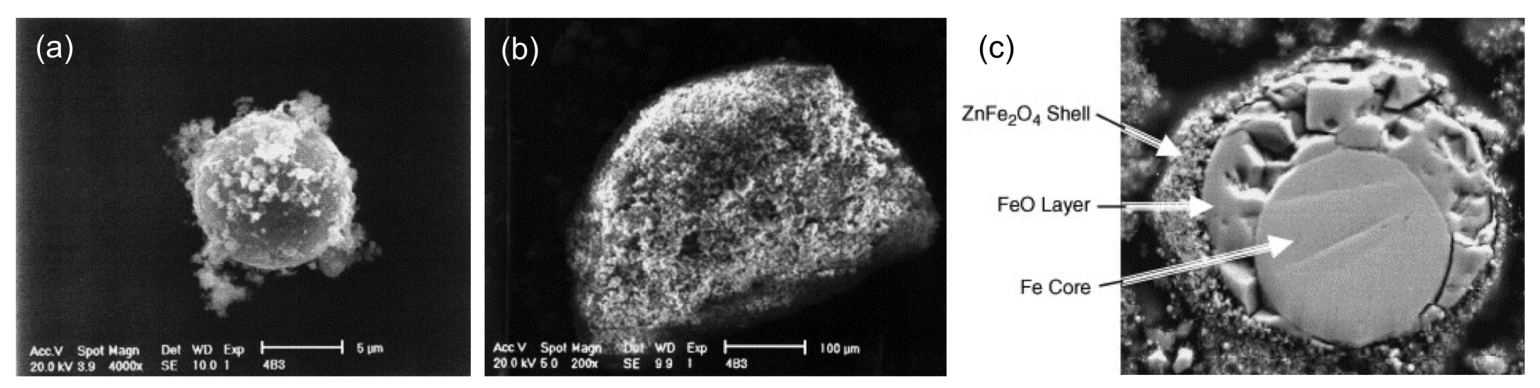

Fig. 3. SEM images of (a) globular spheroid particle, (b) agglomerated particle consisting of submicron particles, and (c) cross sectional view of globular particle showing metallic Fe core (Adapted with permission from Kelebek 2004, copyright Elsevier 2004).

Using SEM Heinreich classified three distinct particle groups within Port Talbot BOS dust (Heinrich 2015). The first and most abundant is described as 'fines', particles sized around $5 \mu \mathrm{m}$. These are consistently produced throughout the blow period, and zinc content is distributed evenly throughout this fraction of the powder. Iron spheres were then described as the next most abundant. These are much larger (up to $500 \mu \mathrm{m}$ ) in diameter and contain less zinc than the finer fraction. The sizing of these particles corresponds well to theoretical calculations of the upper limit of the diameter of a liquid steel droplet to be ejected from steel, which was in the region of $500 \mu \mathrm{m}$ (Hahn 2002).

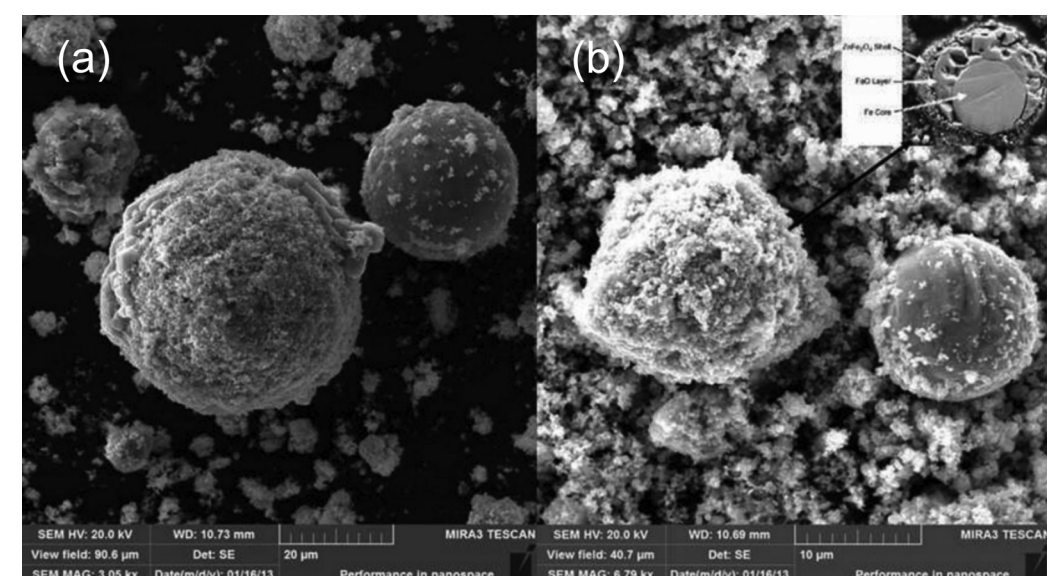

Fig. 4. SEM images of ultrafine particles adhering to the exterior of larger, globular particles (Adapted with permission from Vereš 2015, copyright Taylor and Francis 2015).

\subsection{Chemical analysis.}


The determination of the chemical composition of steelmaking materials is carried out via Xray fluorescence (XRF) spectroscopy or atomic emission/absorption spectroscopy (AES/AAS). $\mathrm{XRF}$ is generally used for analysis for non-trace elements, or in silaceous samples such as in ore characterization, but for zinc determination in BOS dust, digestion of samples followed by inductively coupled plasma atomic emission spectroscopy (ICP-AES) is generally the preferred technique due to its sensitivity to low concentrations and accuracy (Orbaek and Barron 2015) with detection limits for solid samples as low as $2.5 \mathrm{ppm}$ and $0.01 \mathrm{ppm}$ respectively being achievable.

Typical metal analysis of BOS dust from literature is shown in Table 1, from which it is clear that there is a great deal of variability in the overall composition of samples. This is particularly true in the case of zinc and iron content as these are the two key value drivers of metals recovery of BOS dust. Zinc content of BOS dust can be controlled substantially through the elimination of galvanized scrap's inclusion in the scrap charge to the furnace, will levels capable of reaching $0.1-0.2 \mathrm{wt} \% \mathrm{Zn}$ but total elimination of zinc from the material is extremely challenging because of the technical challenges of limiting zinc contamination in merchant scrap and residual levels of zinc within the hot metal itself ( $\sim 50 \mathrm{ppm})$.

\section{Table 1}

Elemental abundance in samples of BOS dust (wt\%).

\begin{tabular}{llllllll}
\hline Source & $\mathrm{Ca}$ & $\mathrm{Fe}$ & $\mathrm{Mg}$ & $\mathrm{Mn}$ & $\mathrm{Pb}$ & $\mathrm{Zn}$ & Reference \\
\hline Unknown & 7.40 & 59.0 & 2.1 & 1.48 & - & 1.48 & Mikhail 1998 \\
Dofasco Hamilton & - & 61.0 & - & - & - & 1.59 & Kelebek 2004 \\
Dofasco Hamilton & - & 50.16 & - & - & - & 2.4 & Goetz 1980 \\
Tata Steel Port & - & - & - & - & - & 4.8 & Steer 2914 \\
Talbot & & & & & & & \\
Tata Steel Port & $3.0-$ & $50.0-80.0$ & $0.20-5.0$ & $0.40-2.20$ & $0.20-1.80$ & $1.7-6.5$ & Heinrich 2015 \\
Talbot & 8.80 & & & & & & \\
\hline
\end{tabular}




\begin{tabular}{lccccccc}
\hline ArcelorMittal & 4.18 & 50.65 & 1.49 & - & 0.07 & 4.37 & Cantarino 2012 \\
Monlevade & & & & & & & \\
(Brazil) & & & & & & & \\
U.S. Steel Kosice & 5.5 & 49.87 & 2.68 & - & 0.24 & 9.37 & Vereš 2015 \\
(Slovakia) & & & & & & & \\
\hline
\end{tabular}

EDX analysis also indicates magnesium and calcium are also present within BOS dust (Vereš 2015), which is likely the result of fine flux additions to the BOS vessel during processing blowing out through the off-gas system and being collected together with the metallic dust (Vereš 2015).

\subsection{Phase determination}

$\mathrm{X}$-ray diffraction (XRD) analysis is a common tool for characterization of the crystalline phases in steelmaking raw materials, products and wastes. It is a relatively insensitive tool with detection limits of around $1 \mathrm{wt} \%$. Quantitative analysis can be challenging as the technique is very matrix dependent but is still very effective for rapid crystallographic analysis. When determining effective recycling solutions for BOS dust an important consideration is the chemical form of the zinc within the material. The two likely candidates are $\mathrm{ZnO}$ (zincite) and $\mathrm{ZnFe}_{2} \mathrm{O}_{4}$ (franklinite) and the relative abundance of these compounds is of great significance. Unfortunately, $\mathrm{Fe}_{3} \mathrm{O}_{4}$ and $\mathrm{ZnFe}_{2} \mathrm{O}_{4}$ have very similar crystallographic unit cells $(\mathrm{Fd} \overline{3} \mathrm{~m})$ and the powder XRD patterns are nearly indistinguishable (Fig. 5), which makes XRD a potentially unreliable measure of the zincite:franklinite ratio present in BOS dust and alternatives need to be explored. Nevertheless, powder XRD can still be a useful tool in exploring the phases present within BOS dust. 


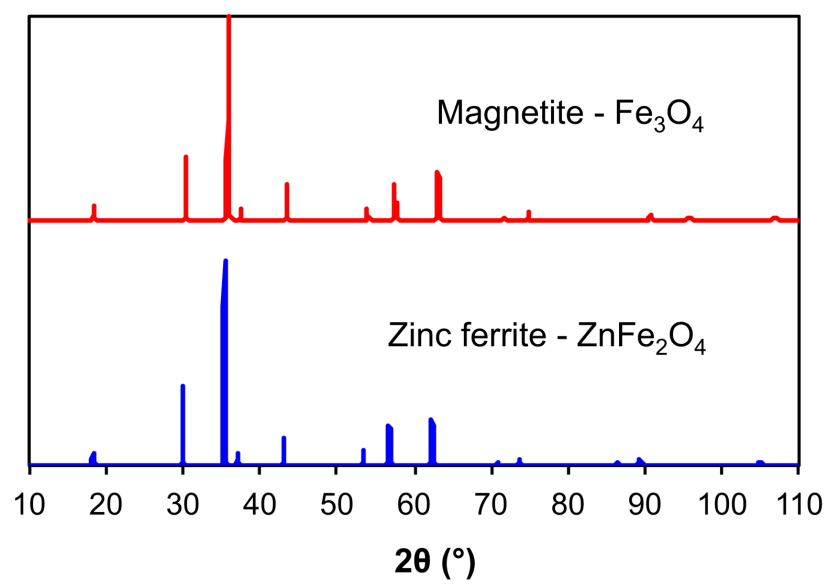

Fig. 5. Calculated powder XRD patterns (using VESTA software) for magnetite \#1011032 (Bragg 1951) and zinc ferrite \#9002487 (Pavese 2000) showing the similarity in diffraction patterns and the difficulty in differentiation.

Reports of the phases present within BOS dust are tremendously varied, which reflects how substantially the conditions within the BOS vessel and off-gas system can affect the chemistry of the by-product. Table 2 shows a selection of phases identified by different authors from steel plants across the world. It is clear from Table 2 that the morphology of BOS dust is drastically variable from plant to plant and even based on the age of the dust that's analyzed and the environment the material was stored in.

\section{Table 2}

Phases identified in BOS dust by powder XRD.

\begin{tabular}{|c|c|c|}
\hline Source & Phases present & Reference \\
\hline Dofasco Hamilton & $\mathrm{FeO}, \mathrm{Fe}_{2} \mathrm{O}_{3}, \mathrm{ZnFe}_{2} \mathrm{O}_{4}$ & Kelebek 2004 \\
\hline Not known & $\alpha-\mathrm{Fe}, \mathrm{FeO}, \mathrm{Fe}_{3} \mathrm{O}_{4}, \mathrm{Fe}_{2} \mathrm{O}_{3}, \mathrm{CaCO}_{3}, \mathrm{SiO}_{2}, \mathrm{ZnO}$ & Gargul 2016 \\
\hline ArcelorMittal Méditerranée & $\mathrm{Fe}_{3} \mathrm{O}_{4}, \mathrm{Fe}_{2} \mathrm{O}_{3}, \mathrm{CaCO}_{3}, \mathrm{C}$ & Sammut 2008 \\
\hline Port Talbot & $\alpha-\mathrm{Fe}, \mathrm{FeO}, \mathrm{Fe}_{3} \mathrm{O}_{4}, \mathrm{Fe}_{2} \mathrm{O}_{3}, \mathrm{CaCO}_{3}, \mathrm{SiO}_{2}, \mathrm{ZnO}, \mathrm{ZnFe}_{2} \mathrm{O}_{4}, \mathrm{C}$ & Jaafer 2014 \\
\hline Port Talbot & $\alpha-\mathrm{Fe}, \mathrm{FeO}, \mathrm{CaCO}_{3}, \mathrm{ZnFe}_{2} \mathrm{O}_{4}$ & Jaafer 2014 \\
\hline Not known & $\mathrm{Fe}_{3} \mathrm{O}_{4}, \mathrm{Fe}_{2} \mathrm{O}_{3}, \mathrm{CaCO}_{3}, \mathrm{Ca}(\mathrm{OH})_{2}, \mathrm{ZnO}, \mathrm{ZnFe}_{2} \mathrm{O}_{4}$ & Mikhail 1998 \\
\hline U.S. Steel Kosice (Slovakia) & $\alpha-\mathrm{Fe}, \mathrm{FeO}, \mathrm{Fe}_{3} \mathrm{O}_{4}, \mathrm{Fe}_{2} \mathrm{O}_{3}, \mathrm{ZnO}, \mathrm{ZnFe}_{2} \mathrm{O}_{4}$ & Veres 2015 \\
\hline
\end{tabular}


The difference between closed and open flue gas hood systems, referred to as suppressed and complete combustion, was investigated using powder XRD (Ray 1997). The differences in the crystalline phases present are stark. In closed hood systems the dust is far more metalized, with the majority of iron present existing in the metallic form $\left(\mathrm{Fe}^{0}\right)$ or as $\mathrm{FeO}$ (i.e., $\mathrm{Fe}^{\mathrm{II}}$ ), while the calcium is present as $\mathrm{CaCO}_{3}$ (calcite). In the open hood systems, where the BOS gas is combusted fully before dedusting (Goetz 1980), the dust is as expected, much more oxidized. Iron exists principally as $\mathrm{Fe}^{\mathrm{III}}$ or mixed $\mathrm{Fe}^{\mathrm{II}} / \mathrm{Fe}^{\mathrm{III}}$ oxides $\left(\mathrm{Fe}_{2} \mathrm{O}_{3}\right.$ and $\mathrm{Fe}_{3} \mathrm{O}_{4}$, respectively), and the calcium tends to be present as $\mathrm{CaO}$ rather than the carbonate. It is likely that the conditions in an open hood off-gas system would favor the formation of $\mathrm{ZnFe}_{2} \mathrm{O}_{4}$ as high temperatures and oxidizing conditions are typical for the production of franklinite (Krishnamurthy 1974).

It has been reported that dust from the Port Talbot (UK) plant, that has been stored outdoors for a number of years, showed significant oxidation of iron to $\mathrm{Fe}_{3} \mathrm{O}_{4}$ and $\mathrm{Fe}_{2} \mathrm{O}_{3}$ compared to a more recent sample (Jaafar 2014). Such 'weathering' is to be expected during outdoor storage.

Calcium in the form of $\mathrm{CaCO}_{3}$ and $\mathrm{CaO}$ is added as a refining flux to the $\mathrm{BOS}$ process and calcium compounds are identifiable in BOS dust as a result. In the heat of the BOS vessel some $\mathrm{CaCO}_{3}$ decomposes to $\mathrm{CaO}$ (Eq. 10).

$\mathrm{CaCO}_{3} \rightarrow \mathrm{CaO}+\mathrm{CO}_{2}$

In the off-gas system, any $\mathrm{CaO}$ reacts with $\mathrm{CO}_{2}$ present and reforms $\mathrm{CaCO}_{3}$ via the reverse reaction. It is worth noting that this carbonation of $\mathrm{CaO}$ happens rapidly within the off-gas system and not as part of the weathering process during storage. Heinrich evidenced this in-situ carbonization through the use of a novel slurry sampling system that showed calcium in BOS dust produced moments prior was already in the form of $\mathrm{CaCO}_{3}$ (Heinrich 2015).

Fig. 6 shows the calculated dominant phases at $1000 \mathrm{~K}$ (approximate BOS gas temperatures within the off-gas system). As the ratio of the partial pressures, $\mathrm{P}_{\mathrm{CO}} / \mathrm{P}_{\mathrm{CO}}$, 
approaches zero as combustion of carbon monoxide nears completion the dominant zinc phase changes from $\mathrm{ZnO}$ to $\mathrm{ZnFe}_{2} \mathrm{O}_{4}$.

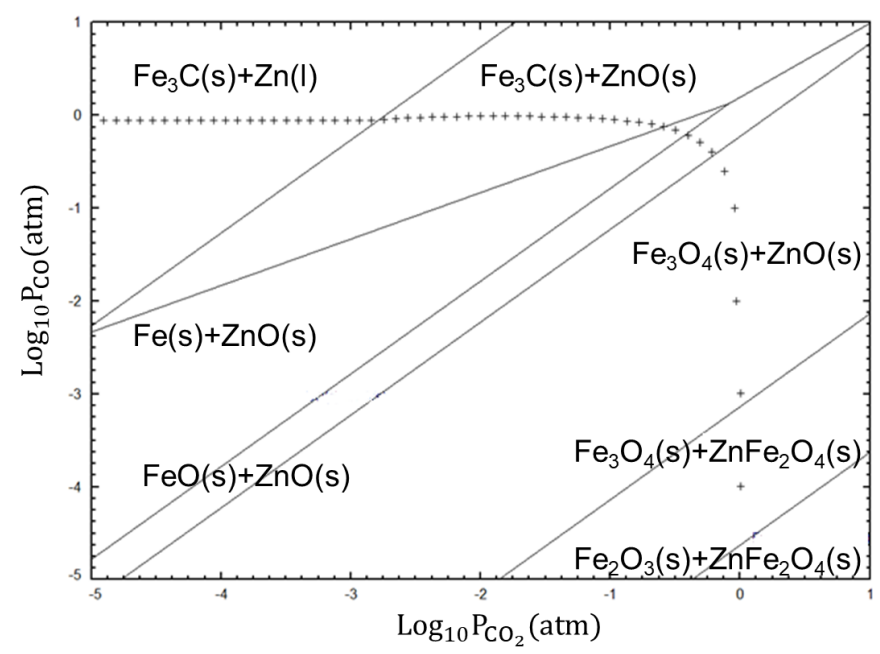

Fig. 6. Predominance diagram for the $\mathrm{Zn}-\mathrm{Fe}-\mathrm{CO}-\mathrm{CO}_{2}$ system at $1000 \mathrm{~K}$. Calculated using FactSage $7.3(\operatorname{Isobar}(+)$ at $1 \mathrm{~atm})$.

$\mathrm{SiO}_{2}$ reported in some samples has likely been introduced into the sample from the splashing of BOS slag during the process (Gargul 2016). Graphitic phases have been reported in a number of studies (Jaafer 2014; Sammut 2008) and these could correspond to the introduction of 'kish' to the sample in the process. As carbon-saturated iron cools the solubility of carbon decreases and a layer of graphite can form on the surface of the liquid in a foliated dendritic structure (Liu 1991). This graphite is known in the steel industry as 'kish' and could be introduced into the BOS off-gas system during charging of pig iron, as kish is prone to become airborne due to its low density.

\subsection{Mössbauer spectroscopy}

Mössbauer spectroscopy has historically been used to characterize oxidation states of iron within iron ores (Salama 2015), as well as a range of other iron containing materials (Zboril 2002; Kuzmann 2003; Rose 2002). While providing insight into the oxidation state and chemical environment of iron within a sample of BOS dust, its principal use in the study of BOS dust is its ability to indirectly differentiate $\mathrm{ZnO}$ from $\mathrm{ZnFe}_{2} \mathrm{O}_{4}$ (Vereš 2015). 
${ }^{57} \mathrm{Fe}$ Mössbauer spectroscopy was used to confirm the chemical environments in which iron was present in the sample. Franklinite was positively confirmed by the presence of a central doublet in the spectrum (Vereš 2015). Total Fe and Zn content was confirmed through digestion and subsequent Atomic Absorption Spectroscopy. The ratio of $\mathrm{ZnO}$ to $\mathrm{ZnFe}_{2} \mathrm{O}_{4}$ could then be calculated and for the BOS dust used in the study, the sample was $13.47 \mathrm{wt} \% \mathrm{ZnFe}_{2} \mathrm{O}_{4}$ and 7.10 $\mathrm{wt} \% \mathrm{ZnO}$. This suggests that the ratio of zinc existing in the $\mathrm{ZnO}: \mathrm{ZnFe}_{2} \mathrm{O}_{4}$ forms is $60: 40$; however, it is critical to note that from the work in question it is unclear whether the plant in Slovakia that the dust was generated by has an open or closed hood off-gas system (Vereš 2015). The abundance of higher Fe oxides and lack of metallic iron present within the sample, would suggest a combustive process, which may lead to a greater degree of zinc existing in the franklinite form.

Mössbauer spectroscopy shows tremendous potential for the analysis of zinc in steelmaking wastes as the $\mathrm{ZnO} / \mathrm{ZnFe}_{2} \mathrm{O}_{4}$ ratio has huge implications for extractive process selection, see below.

\section{Pyrometallurgical separation techniques}

Based upon a thermodynamic modelling study (Hay \& Rankin 1994) it was proposed that a range of operating regimes and choice of process were feasible for the pyrometallurgical treatment of BOS dust to remove the zinc (and other volatile elements) and reuse the iron as hot metal, metallized clinker or iron oxide clinker. As such pyrometallurgical processes for removal of zinc from steelmaking by-products are somewhat well established and offer some attractive features such as good scalability and (generally) continuous processing. Pyrometallurgical separation plants are, however, usually capital intensive, with high setup costs and energy demand. Consequently, in the case of separation of iron and zinc in steel byproduct recovery, carbothermal reduction and separation by volatilization is the industry standard. An obvious downside of carbothermal reduction is the production of $\mathrm{CO}_{2}$ as an intrinsic product of the process, creating greater carbon emissions to an industry already having to struggling to meet the challenges of decarbonization (Worrell 2001; Lin \& Wang 2015; Kim

\& Wang 2002; Allwood 2010; Gielen \& Moriguchi 2002). Pyrometallurgical plants also 
generally produce a large amount of dust and noise, which must be taken into consideration when assessing plant feasibility.

The relatively high volatility of zinc relative to iron means that it can be physically separated from BOS dust by heating under reducing conditions. Carbon is gasified through the Boudouard reaction (Eq. 11) and then $\mathrm{ZnO}$ is reduced to elemental $\mathrm{Zn}$ vapor by carbon monoxide (Eq. 12).

$\mathrm{C}+\mathrm{CO}_{2} \rightarrow 2 \mathrm{CO}$

$\mathrm{ZnO}+\mathrm{CO} \rightarrow \mathrm{Zn}+\mathrm{CO}_{2}$

Zinc in the vapor phase readily oxidizes in the presence of $\mathrm{CO}_{2}$ to reform $\mathrm{ZnO}$ via the reverse reaction. Zinc ferrite reduces in a similar fashion, reacting with CO (Eq. 13) or thermal decomposition of $\mathrm{ZnFe}_{2} \mathrm{O}_{4}$ to $\mathrm{ZnO}$ (Eq. 14) between $719^{\circ} \mathrm{C}$ and $1050{ }^{\circ} \mathrm{C}$ (Lee 2001).

$3 \mathrm{ZnFe}_{2} \mathrm{O}_{4}+4 \mathrm{CO} \rightarrow 3 \mathrm{Zn}+2 \mathrm{Fe}_{3} \mathrm{O}_{4}+2 \mathrm{CO}_{2}$

$\mathrm{ZnFe}_{2} \mathrm{O}_{4} \rightarrow \mathrm{ZnO}+2 \mathrm{Fe}_{2} \mathrm{O}_{3}$

Under hot, reducing conditions such as these, reduction of iron oxides also occurs, which is very favorable for ferrous recovery, because a semi-metalized iron product from the separation process has considerable benefits for an integrated steelworks. Direct reduced iron (DRI), or sponge iron, can be directly charged into the iron making process, thus reducing reductant rates within the blast furnace, displacing expensive coke, and improving the process economy (Stephenson \& Smailer 1999).

DRI can be produced in a variety of ways, including countercurrent shaft furnaces utilizing reformed natural gas, fluidized beds and others (Anameric \& Kawatra 2007; Chatterjee 2012), but the critical consideration for processing zinc-bearing materials is the direction of gas flow relative to the oxidizing gradient. In order to prevent condensation and recirculation of zinc within the furnace, the oxidizing gradient must be perpendicular to the material flow 
direction: to carry condensed zinc oxide away from the ferrous burden. This effectively rules out the countercurrent natural gas reduction units such as the Midrex ${ }^{\circledR}$ process often used to produce DRI at mine sites (Atushi 2010). Fig. 7 provides an outline of the process (Fruehan 2005).

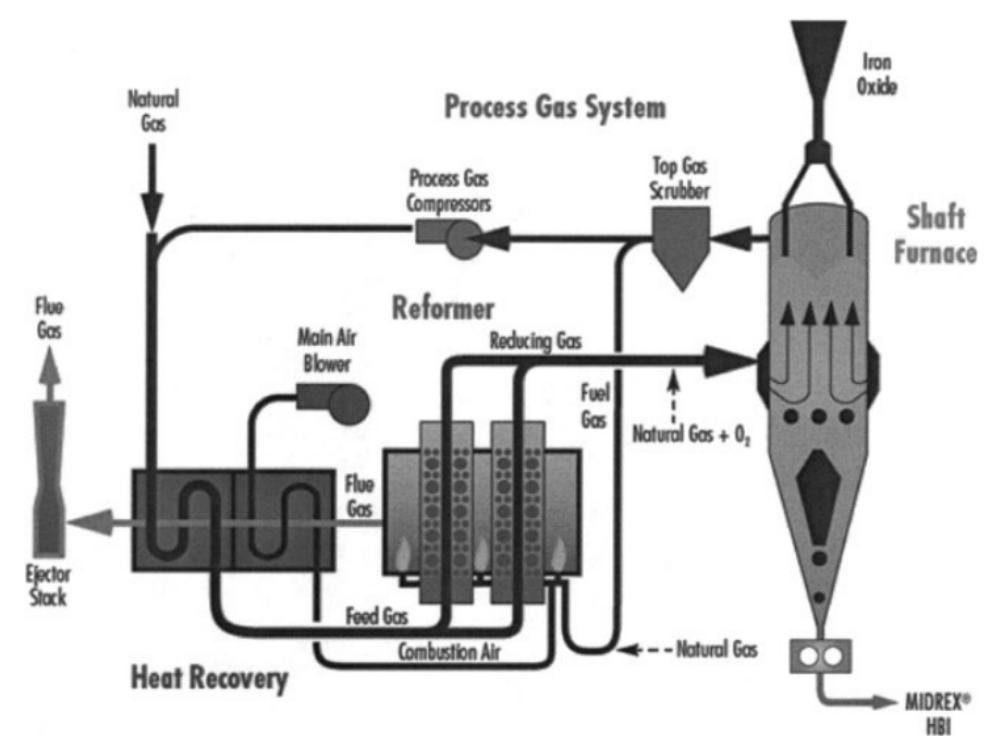

Fig. 7. Simplified schematic process flow for a two-stage natural gas DRI plant such as Midrex ${ }^{\circledR}$ (Reproduced with permission from Fruehan 2005. Copyright Taylor \& Francis).

Solid based reduction processes are much more effective in the processing of zincbearing by-products. Common reductant sources include coke breeze, pulverized coal, and carbon-bearing revert material such as blast furnace dust (Ahmed 2018). Table 3 compares gas direct reduction and solid fuel direct reduction to conventional blast furnace pig iron production. Seeing as both the gas-solid and blast furnace are both unsuitable for $\mathrm{Zn}$ bearing by-products such as BOS dust this review will only discuss in detail the solid-solid DRI producing processes that can tolerate high zinc loadings.

\section{Table 3}

Comparison of DRI production processes with traditional blast furnace production.

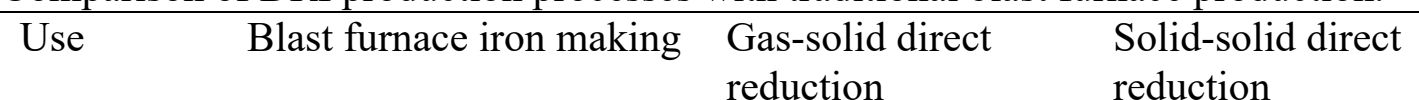




\begin{tabular}{|c|c|c|c|}
\hline $\begin{array}{l}\text { Reducing } \\
\text { agent }\end{array}$ & $\begin{array}{l}\text { Coke, can be } \\
\text { supplemented with } \\
\text { pulverized coal/tar } \\
\text { injection }\end{array}$ & $\begin{array}{l}\text { Reformed natural } \\
\text { gas, by-product } \\
\text { gases such as coke } \\
\text { oven gas (COG) }\end{array}$ & $\begin{array}{l}\text { Coal, coke breeze, } \\
\text { carbon-bearing revert } \\
\text { material }\end{array}$ \\
\hline $\begin{array}{l}\text { Ferrous } \\
\text { input } \\
\text { material }\end{array}$ & $\begin{array}{l}\text { Sinter, ore, DRI. Low } \\
\text { volatile metal content is } \\
\text { critical }\end{array}$ & $\begin{array}{l}\text { Limited to ore, } \\
\text { volatile metal } \\
\text { loading similar to a } \\
\text { blast furnace }\end{array}$ & $\begin{array}{l}\text { Flexible: ore, waste } \\
\text { oxides, etc. Volatile } \\
\text { metals are not restricted }\end{array}$ \\
\hline $\begin{array}{l}\text { Input } \\
\text { material } \\
\text { form }\end{array}$ & $\begin{array}{l}\text { No fine material, } \\
\text { pellets/lump ore. Must } \\
\text { have sufficient strength to } \\
\text { withstand furnace } \\
\text { conditions }\end{array}$ & $\begin{array}{l}\text { Pellets, lump, some } \\
\text { processes utilize } \\
\text { fine material such as } \\
\text { fluidized bed } \\
\text { processes }\end{array}$ & $\begin{array}{l}\text { Pellets or fine material, } \\
\text { depending on the specific } \\
\text { process }\end{array}$ \\
\hline $\begin{array}{l}\text { Furnace } \\
\text { design }\end{array}$ & $\begin{array}{l}\text { Large vertical shaft } \\
\text { furnace, charged from the } \\
\text { top with a hot blast fed in } \\
\text { through tuyeres at base }\end{array}$ & $\begin{array}{l}\text { Typically, a vertical } \\
\text { shaft furnace }\end{array}$ & $\begin{array}{l}\text { Rotating kiln or rotary } \\
\text { hearth furnace }\end{array}$ \\
\hline Product & Molten pig iron & Direct reduced iron & $\begin{array}{l}\text { Direct reduced iron or } \\
\text { Waelz slag depending on } \\
\text { the process }\end{array}$ \\
\hline $\begin{array}{l}\text { Product } \\
\text { quality }\end{array}$ & $\begin{array}{l}\text { Very high quality, } \\
\text { complete separation of Fe } \\
\text { and gangue. Slag formed } \\
\text { has some desulfurizing } \\
\text { capacity }\end{array}$ & $\begin{array}{l}\text { Usually, excellent } \\
\text { quality depending } \\
\text { on the quality of the } \\
\text { ore and reducing gas }\end{array}$ & $\begin{array}{l}\text { Dependent on feedstock } \\
\text { material and coal quality. } \\
\text { Usually unsuitable for } \\
\text { EAF/BOS use due to high } \\
\text { S and gangue content }\end{array}$ \\
\hline $\begin{array}{l}\text { By- } \\
\text { products }\end{array}$ & $\begin{array}{l}\text { Liquid slag, dusts, caloric } \\
\text { off-gas which can be } \\
\text { reused to heat stoves }\end{array}$ & $\begin{array}{l}\text { Caloric off-gas } \\
\text { which can be } \\
\text { combusted to heat } \\
\text { process, dusts }\end{array}$ & $\begin{array}{l}\text { Off-gas fully combusted } \\
\text { in situ, baghouse dust } \\
\text { contains } \mathrm{ZnO} \text { product } \\
\text { suitable for sale }\end{array}$ \\
\hline
\end{tabular}

\subsection{The Waelz kiln.}

One of the oldest treatments for zinc containing dusts, the Waelz process, involves the heating of dust mixed intimately with a carbon fuel, then heated $>1,000{ }^{\circ} \mathrm{C}$ in a rotating kiln, and fired by a burner at the exit end of the tunnel (Fig. 8). A typical Waelz kiln is around $50-70 \mathrm{~m}$ long with a diameter of 4-5 m. The zinc containing compounds are reduced, volatilized and consequently reoxidize in the gas stream, thus, separating the zinc from the ferrous material. 


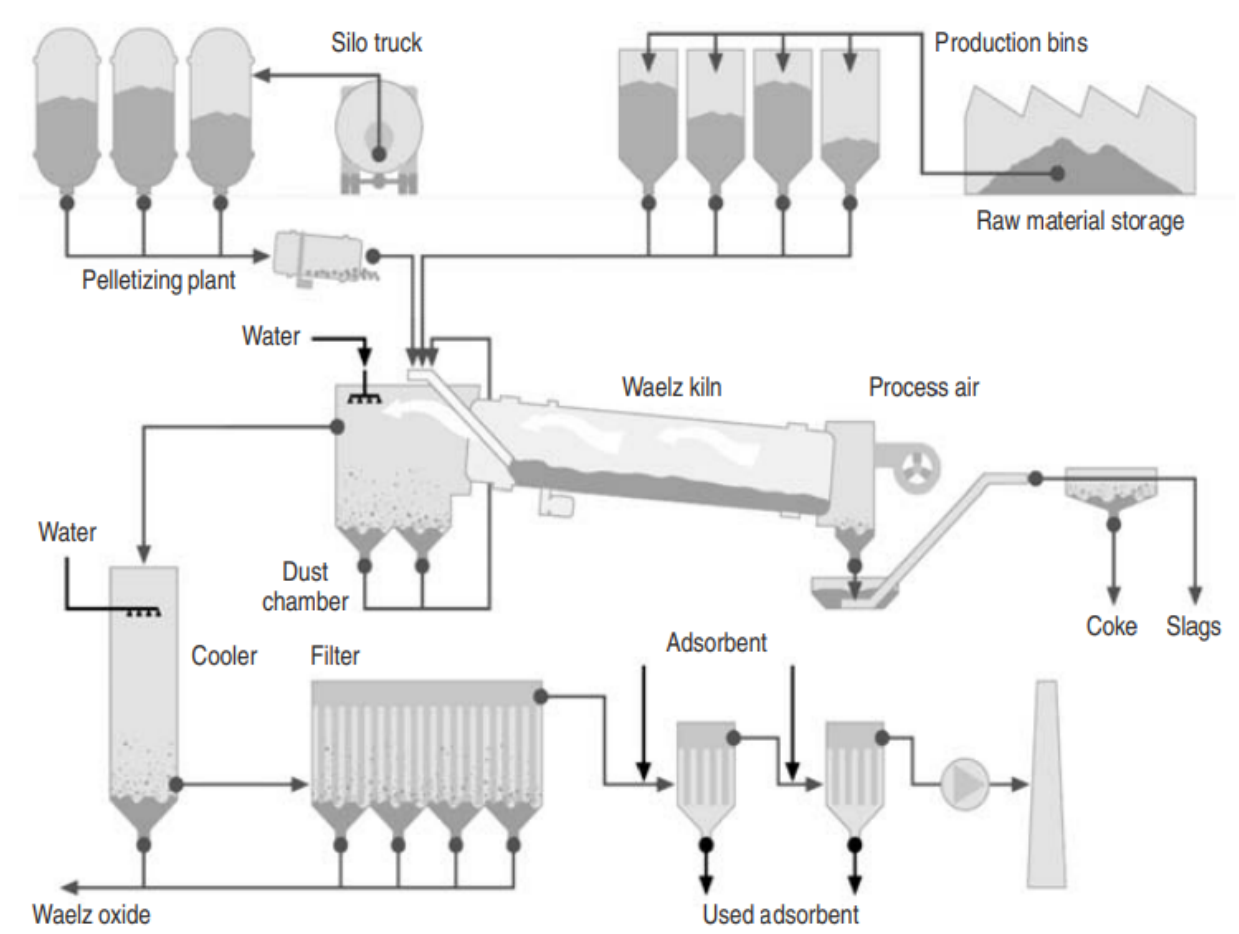

Fig. 8. Schematic representation of the Waelz kiln process (Reproduced with permission from Mager 2013. Copyright Springer-Verlag).

The charge for the furnace is prepared by pelletizing and is charged at the top (entry end) of the furnace, as the drum rotates the burden transits down the drum and reacts with the reducing gas generated from the carbon source. The process has several disadvantages, such as long retention times of up to 8 hours that lead to very low productivity. Typically, Waelz kilns found use in the recovery of zinc from EAF dust or zinc ores with a mineral content too low for more traditional mineral dressing (Porter 1991). Waelz kiln processing is globally well established with over 1 million tons of capacity for EAF dust in the late 1990s (Mager 2000), which increased to the 3.4 million tons of EAF dust capacity across 35 kilns currently operating globally (Masson \& Briol 1969). However, the Waelz kiln cannot economically process material lower in zinc than around $10 \mathrm{wt} \%$, due to the relatively low value of the iron-bearing product and the thermal inefficiency of the process.

Table 4 shows a typical chemical analysis from a Waelz kiln of the input material (EAF dust), the ferrous product and the zinc-rich 'waelz oxide' collected through the off-gas dedusting system. Often fluxes are added to the infeed to manage slag chemistry and prevent 
accretions or 'slag rings' forming within the kiln at specific thermal zones. These rings or accretions can reduce productivity through disruption solid material flow through the furnace, attacking refractory and increase maintenance costs. Of course, the addition of fluxes in the form of mineral oxides are not a perfect solution however, as introducing gangue material into the ferrous burden decreases its value in use for recycling purposes.

\section{Table 4}

Chemical analysis (Wt\%) of the inputs and products of the Waelz kiln process (Mager 2000).

\begin{tabular}{llll} 
Element or compound & EAF dust & Ferrous product & Waelz oxide \\
\hline $\mathrm{Wn} \%$ & $\mathrm{Wt} \%$ & $\mathrm{Wt} \%$ \\
$\mathrm{~Pb}$ & $18.0-25.0$ & $0.2-2.0$ & $55.0-58.0$ \\
$\mathrm{Cd}$ & $2.0-7.0$ & $0.5-1.0$ & $7.0-10.0$ \\
$\mathrm{~F}$ & $0.03-0.1$ & $<0.01$ & $0.1-0.2$ \\
$\mathrm{Cl}$ & $0.2-0.5$ & $0.1-0.2$ & $0.4-0.7$ \\
$\mathrm{C}$ & $1.0-4.0$ & $0.03-0.05$ & $4.0-8.0$ \\
$\mathrm{FeO}$ & $1.0-5.0$ & $3.0-8.0$ & $0.5-1.0$ \\
$\mathrm{Fe}_{\mathrm{met}} / \mathrm{Fe}$ & $20.0-38.0$ & $30.0-50.0$ & $4.0-7.0$ \\
$\mathrm{CaO}$ & - & $80.0-90.0$ & - \\
$\mathrm{SiO}_{2}$ & $6.0-9.0$ & $15.0-25.0$ & $0.7-1.2$ \\
$\mathrm{Na}_{2} \mathrm{O}$ & $3.0-5.0$ & $6.0-12.0$ & $0.5-1.0$ \\
$\mathrm{~K}_{2} \mathrm{O}$ & $1.5-2.0$ & $1.2-1.6$ & $0.1-0.2$ \\
\hline
\end{tabular}

\subsection{The rotary hearth furnace}

Initially patented in the 1960 s the rotary hearth furnace process takes advantage of the high reaction speeds afforded through the firing of self-reducing composite pellets of iron oxide and carbon. A rotary hearth furnace (RHF) consists of a circular turntable rotating inside of a refractory lined tunnel (Fig. 9). Heat is supplied by natural gas or pulverized coal burners, but the majority of the process heat comes from the combustion of the carbon source within the 
charge itself. The gas flow is countercurrent to the material flow so hot process gases can preheat the freshly charged pellets, resulting in good heat exchange and thermal efficiency.

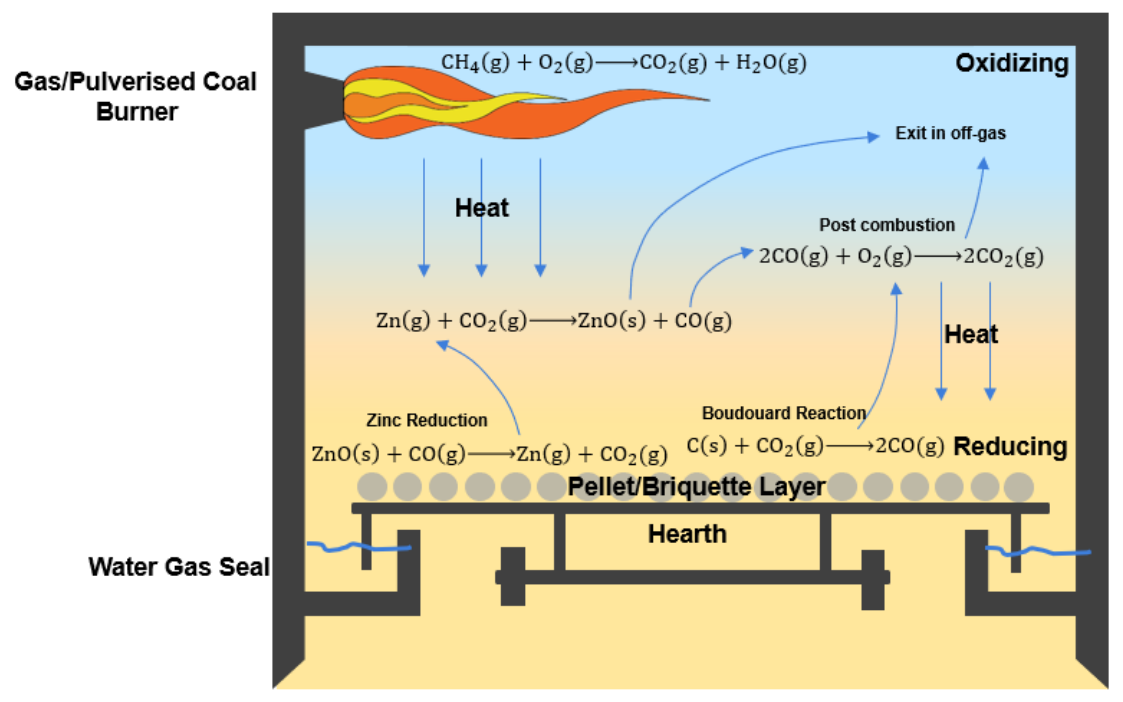

Fig. 9. A schematic cross-sectional view of the zinc removal mechanism in the rotary hearth furnace (RHF).

RHFs can accommodate a far wider range of materials than a BF, due to the lack of vertical loading of the furnace burden. In the BF, pellets nearer the bottom of the stack must support the mass of the burden above it. Typically blast furnace pellets must have a cold compression strength of $>2450 \mathrm{~N}$ per pellet to withstand the compressive load of the furnace (Lu 2015). In the RHF, the burden layer is at most 3 pellets thick. As such it is permissible to charge materials with far less compressive strength: $>40 \mathrm{~N}$ per pellet is acceptable to be charged to the furnace.

There are many different commercialized processes for direct reduction using an RHF such as FASTMET ${ }^{\circledR}$, DRyIron ${ }^{\circledR}$, and INMETCO $^{\circledR}$ but all follow very similar process principals. The chemical process remains the same for each process (Table 5), the carbon source in the pellets begins to gasify to form a localized reducing atmosphere within and proximal to the furnace burden. The $\mathrm{CO}$ then reduces the iron oxides stepwise to metallic iron, as well as volatilizing any $\mathrm{Zn}$ and $\mathrm{Pb}$ present. Solid state reduction also occurs between $\mathrm{C}$ and $\mathrm{Fe}_{\mathrm{x}} \mathrm{O}_{\mathrm{y}}$ but this is slow and much less significant. Post-combustion of $\mathrm{CO}$ to $\mathrm{CO}_{2}$ is exothermic and 
supplies more thermal energy to the process to drive the endothermic gasification and reduction reactions.

\section{Table 5}

Principal chemical reactions occurring in a rotary hearth furnace.

\begin{tabular}{|c|c|c|}
\hline Process stage & Reaction & Equation \\
\hline \multirow{4}{*}{$\begin{array}{l}\text { Gasification } \\
\text { of carbon }\end{array}$} & Devolatilization of coal & coal $\rightarrow \mathrm{H}_{2}, \mathrm{H}_{2} \mathrm{O}, \mathrm{CO}, \mathrm{CH}_{4}$ \\
\hline & Combustion & $\mathrm{C}+\mathrm{O}_{2} \rightarrow \mathrm{CO}_{2}$ \\
\hline & Boudouard reaction & $\mathrm{C}+\mathrm{CO}_{2} \rightarrow 2 \mathrm{CO}$ \\
\hline & Water gas shift & $\mathrm{CO}_{2}+\mathrm{H}_{2} \rightarrow \mathrm{CO}+\mathrm{H}_{2} \mathrm{O}$ \\
\hline \multirow{4}{*}{ Zinc removal } & $\begin{array}{l}\text { Carbothermal zincite } \\
\text { reduction }\end{array}$ & $\mathrm{ZnO}+\mathrm{CO} \rightarrow \mathrm{Zn}+\mathrm{CO}_{2}$ \\
\hline & $\begin{array}{l}\text { Zinc ferrite thermal } \\
\text { decomposition }\end{array}$ & $\mathrm{ZnFe}_{2} \mathrm{O}_{4} \rightarrow \mathrm{ZnO}+2 \mathrm{Fe}_{2} \mathrm{O}_{3}$ \\
\hline & Zinc ferrite reduction & $\begin{array}{l}3 \mathrm{ZnFe} 2 \mathrm{O}_{4}+4 \mathrm{CO} \rightarrow 3 \mathrm{Zn}+2 \mathrm{Fe}_{3} \mathrm{O}_{4}+ \\
2 \mathrm{CO}_{2}\end{array}$ \\
\hline & $\begin{array}{l}\text { Reduction of zincite by } \\
\text { hydrogen }\end{array}$ & $\mathrm{ZnO}+\mathrm{H}_{2} \rightarrow \mathrm{Zn}+\mathrm{H}_{2} \mathrm{O}$ \\
\hline \multirow{2}{*}{$\begin{array}{l}\text { Iron } \\
\text { reduction }\end{array}$} & $\begin{array}{l}\text { Carbothermal reduction of } \\
\text { iron }\end{array}$ & $\begin{array}{l}\mathrm{Fe}_{2} \mathrm{O}_{3}+\mathrm{CO} \rightarrow 2 \mathrm{Fe}_{3} \mathrm{O}_{4}+\mathrm{CO}_{2} \\
\mathrm{Fe}_{3} \mathrm{O}_{4}+\mathrm{CO} \rightarrow 3 \mathrm{FeO}+\mathrm{CO}_{2} \\
\mathrm{FeO}+\mathrm{CO} \rightarrow \mathrm{Fe}+\mathrm{CO}_{2}\end{array}$ \\
\hline & Reduction of iron by hydrogen & $\begin{array}{l}\mathrm{Fe}_{2} \mathrm{O}_{3}+\mathrm{H}_{2} \rightarrow 2 \mathrm{Fe}_{3} \mathrm{O}_{4}+\mathrm{H}_{2} \mathrm{O} \\
\mathrm{Fe}_{3} \mathrm{O}_{4}+\mathrm{H}_{2} \rightarrow 3 \mathrm{FeO}+\mathrm{H}_{2} \mathrm{O} \\
\mathrm{FeO}+\mathrm{H}_{2} \rightarrow \mathrm{Fe}+\mathrm{H}_{2} \mathrm{O}\end{array}$ \\
\hline \multirow{2}{*}{$\begin{array}{l}\text { Iron } \\
\text { carburization }\end{array}$} & Gas carburization & $3 \mathrm{Fe}+2 \mathrm{CO} \rightarrow \mathrm{Fe}_{3} \mathrm{C}+\mathrm{CO}_{2}$ \\
\hline & Solid carburization & $3 \mathrm{Fe}+\mathrm{C} \rightarrow \mathrm{Fe}_{3} \mathrm{C}$ \\
\hline
\end{tabular}

A key advantage of the RHF over the Waelz kiln is an increase in the quality of the $\mathrm{ZnO}$ product due to the lower contamination with fine iron material, due to the large pellets not abrading against each other to generate excess iron fines. Excessive contamination of iron is undesirable for zinc reprocessing purposes. The addition of fluxes is usually also unnecessary allowing for increased furnace productivity and a higher value DRI product. 


\subsection{FASTMET ${ }^{\circledR}$.}

Developed by Kobe Steel, FASTMET ${ }^{\circledR}$ is one of the most commercially established RHF processes globally, with around a million tonnes of steelmaking waste processing capacity spread across six plants in Japan (Kobelco 2019). Fig. 10 shows a schematic of the FASTMET ${ }^{\circledR}$ process flow.

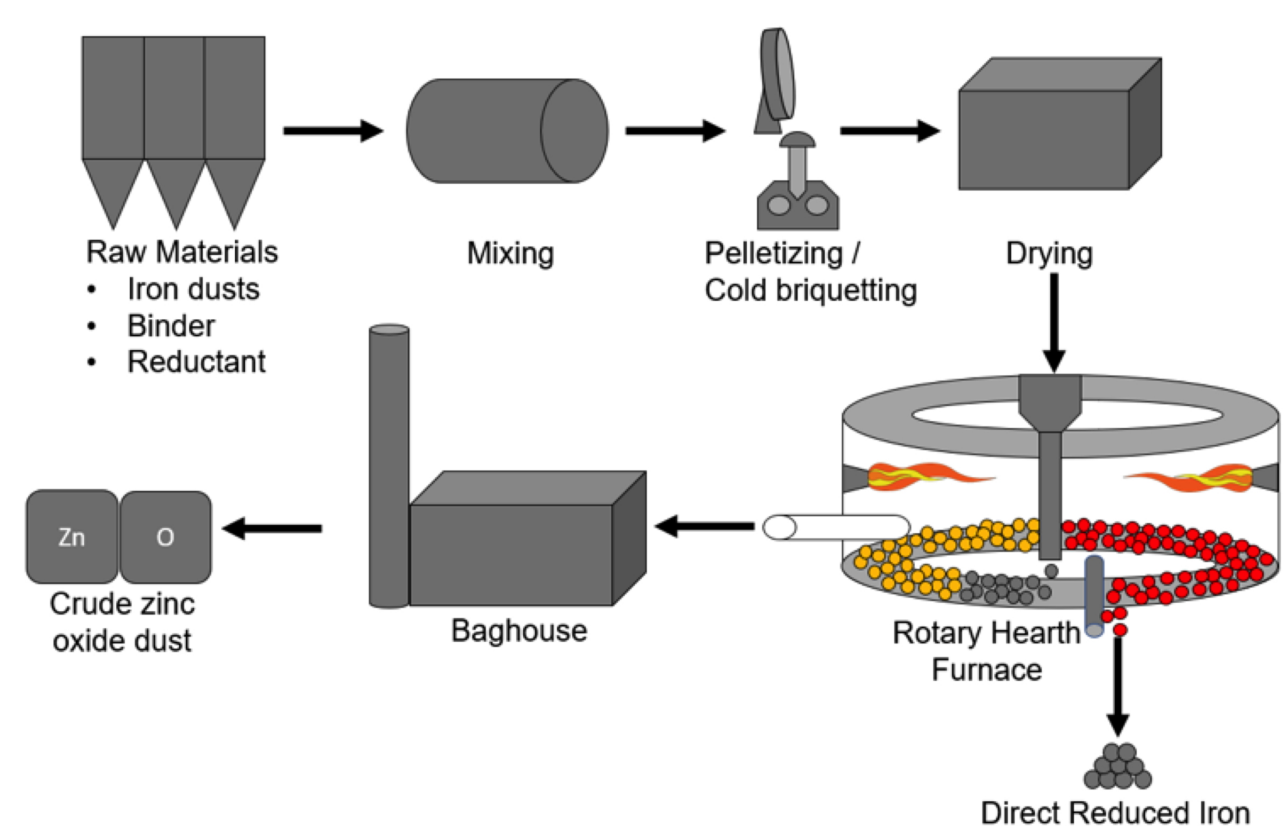

Fig. 10. Simplified schematic of the FASTMET ${ }^{\circledR}$ process flow.

Pellets are produced by the blending of iron bearing material with a stoichiometric amount of carbon (coal, coke breeze, or carbon-bearing revert material) with a binding agent. These pellets are charged in one or two layers onto the hearth floor. The composite pellets are then heated to around $1300-1350{ }^{\circ} \mathrm{C}$ and over the course of 8-16 minutes react and are discharged via a water-cooled rotating screw.

Hot DRI is discharged from the exit end of the furnace which can either be held in nitrogen purged canisters for hot charging to the EAF melt shop or turned into hot briquetted iron (HBI). HBI can then be more readily stored for later use in a blast furnace. An important acknowledgment of the typical product chemistry (Table 6) is the sulfur content of the DRI produced from by-product material. Often DRI produced from recycled materials is unfit for recharging directly into the BOF due to sulfur limitations, instead of being routed to the blast 
furnace. While this does indeed recycle the ferrous material into hot metal, DRI has a lower value in use when charged to the BF than the BOF as a scrap replacement.

\section{Table 6}

Typical chemistry of steelmaking by-product input and DRI output of a FASTMET ${ }^{\circledR}$ RHF (Chatterjee 2012).

\begin{tabular}{lllllll} 
Material & $\mathrm{Fe}(\mathrm{wt} \%)$ & $\mathrm{FeO}(\mathrm{wt} \%)$ & $\mathrm{C}(\mathrm{wt} \%)$ & $\mathrm{S}(\mathrm{wt} \%)$ & $\mathrm{Zn}(\mathrm{wt} \%)$ & $\mathrm{Fe}_{\mathrm{Met}} / \mathrm{Fe}$ \\
\hline BF dust & 40.1 & 19.2 & 31.0 & 0.42 & 0.01 & - \\
BF Sludge & 33.0 & 10.6 & 31.4 & 0.49 & 0.14 & - \\
BOS Sludge & 63.2 & 64.4 & 0.74 & 0.1 & 0.43 & - \\
Fastmet DRI & 70.5 & - & 1.13 & 0.35 & 0.004 & $95 \%$ \\
\hline
\end{tabular}

Variants of FASTMET ${ }^{\circledR}$ such as FASTMELT $^{\circledR}$ incorporate a DRI melting unit to produce hot metal directly using a submerged arc furnace, however these units have an increased energy demand and would likely be uneconomical for use within an integrated works.

\subsection{INMETCO process}

The INMETCO (International Metals Reclamation Company, Inc.) process is very similar to FASTMET $^{\circledR}$, in that it also utilizes cold bonded carbon-iron oxide material composite pellets as feedstock to a rotary hearth furnace. Typically for INMETCO 20-25\% volatile content coal is used as a reducing agent.

The process was initially developed to processing stainless steelmaking wastes for $\mathrm{Ni}$ and Cr recovery (Espinosa 2004), but its scope also extends to Zn recovery from EAF dust. The key point of difference between FASTMET ${ }^{\circledR}$ and INMETCO is the number of pellet layers charged to the furnace simultaneously (Fig. 11). INMETCO utilizes a multiple layer system around $30 \mathrm{~mm}$ in depth (and accordingly has a higher furnace residence time for the material) whereas FASTMET ${ }^{\circledR}$ is operated on a monolayer basis. Multiple layers of pellets can lead to inhomogeneity of the DRI product, with the top layers reacting substantially quicker than the base layer; however, the thermal load on the furnace hearth is lower than in monolayer 
processes. The process is also highly dependent on green pellet strength as not only must the pellets survive the manual handling required to charge them to the furnace, but they must also have sufficient strength to handle the weight of pellets above them as well as the rapid vaporization of the contained moisture and volatiles within the composites.

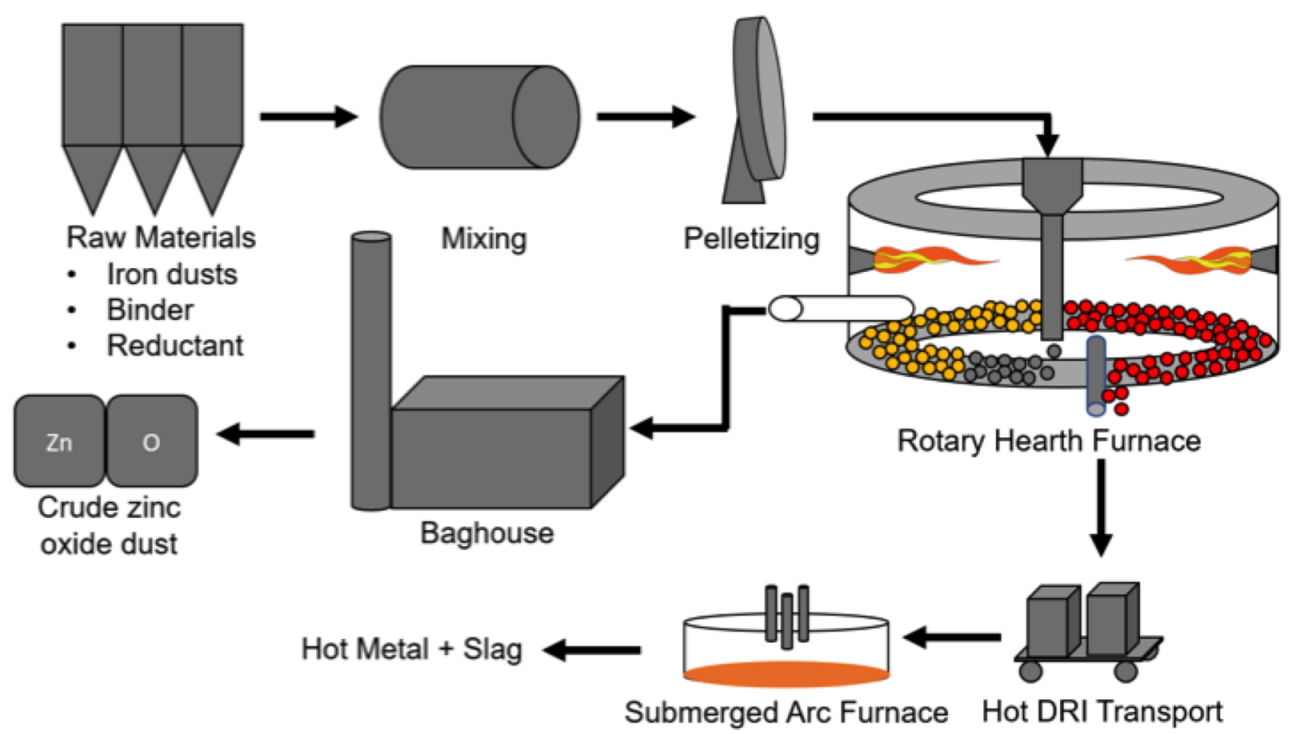

Fig. 11. Simplified schematic of the INMETCO process flow.

The only commercial plant operating the INMETCO process is in Ellwood City, PA (Money 2000) and has been in continuous operation since 1976 processing stainless steel wastes. This plant is integrated into a submerged arc furnace unit that converts the DRI produced into hot metal, which is subsequently cast into ingots suitable as feedstock for the stainless steel industry. The Ellwood city plant produces $20 \mathrm{kt}$ of pig iron ingots per annum, with a raw material capacity of $50 \mathrm{kt}$ per annum (Hanewald 1992). Zinc is effectively eliminated from the output material partially due to the RHF reduction step and also due to the iron smelting step in the submerged arc furnace.

\subsection{DRyIron ${ }^{\mathrm{TM}}$ process}

The DRyIron $^{\mathrm{TM}}$ process is again, very similar to FASTMET ${ }^{\circledR}$ and INMETCO. The fundamental difference is that DRyIron ${ }^{\mathrm{TM}}$ is fed exclusively by cold briquetted material (Fig. 12) and has found commercial use preparing DRI from BOS dust and blast furnace dust. Global capacity 
for this process is currently around $1.25 \mathrm{mt}$ per annum (Seetharaman 2013), making DRyIron ${ }^{\text {TM }}$ one of the most commercially successful rotary hearth furnace processes. This capacity is almost entirely concentrated in the East Asian steel industry in countries such as South Korea, Japan, and China following the closure of plants in the USA in the early 2000s.

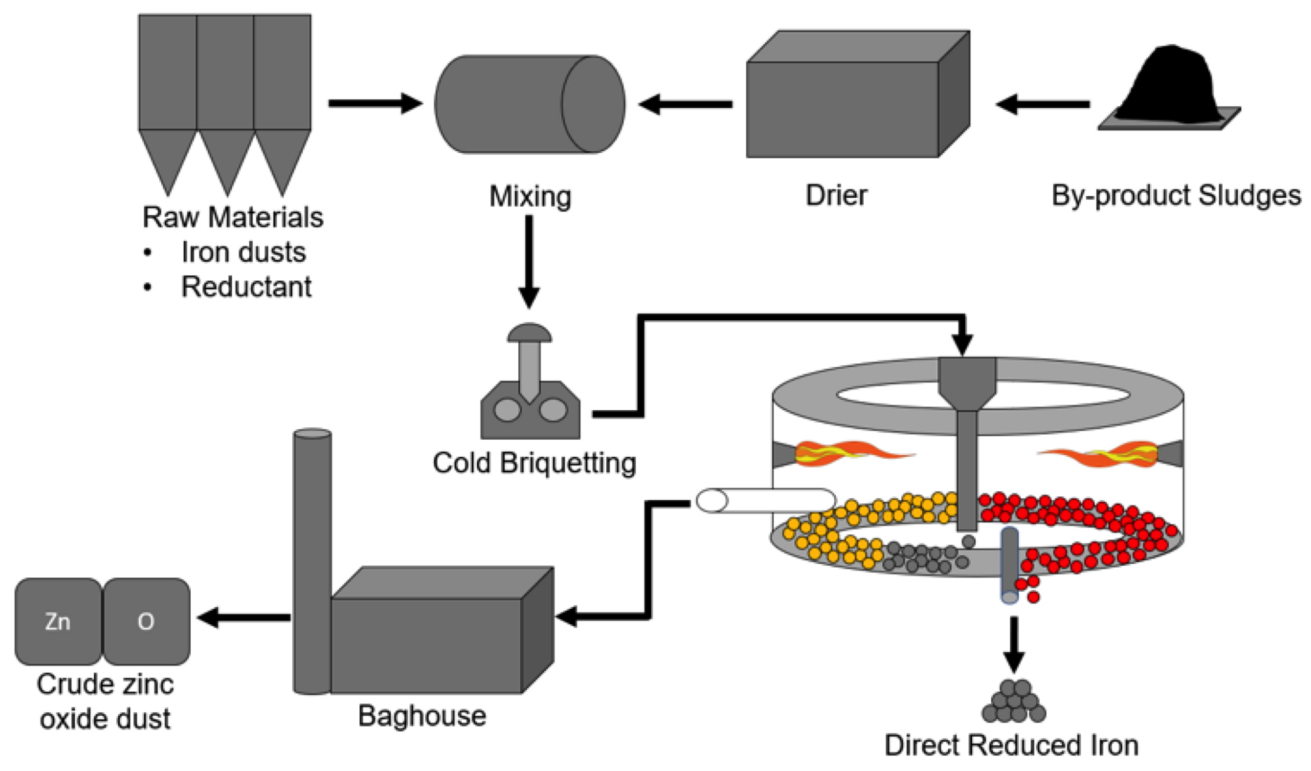

Fig. 12. Simplified schematic for the DRyIron ${ }^{\mathrm{TM}}$ process flow.

The reason for the favorability of the DRyIron ${ }^{\mathrm{TM}}$ process for handling of zinc bearing wastes from an integrated steel plant is that cold briquetting processes can utilize exceptionally fine material and produce a product with consistent size and density. With regard to zinc removal this is critical as a tight size and distribution of in feed material ensures consistent and homogenous zinc removal, which is vital to ensure the recyclability of the DRI produced to the blast furnace.

DRyIron $^{\mathrm{TM}}$ also does not utilize a binder in the briquetting process. Binderless briquetting has two key advantages: reduced preparation costs and reduced gangue in the DRI product. Metallization levels of 95\% are achievable in short residence times of 10-15 minutes and residual levels of $\mathrm{P}$ and $\mathrm{S}$ in the DRI can be managed through reductant selection (Chatterjee 2012; Rinker 2001). 
Unlike the FASTMET $^{\circledR}$ process, material is dried prior to the agglomeration step rather than after forming. This can provide advantages with the consistency of the forming process, as steelmaking by-product dusts can be tremendously variable depending on the method by which they were scrubbed from off-gas (venturi scrubbers versus electrostatic systems) and their storage conditions.

The produced DRI from DRyIron ${ }^{\mathrm{TM}}$ is around $80 \%$ metallized and are suitable for hot charging to an EAF, or under controlled inert cooling conditions can be subsequently used in the blast furnace depending on raw material selection.

\subsection{ITmk3}

ITmk3 is an evolution of the FASTMET ${ }^{\circledR}$ and FASTMELT ${ }^{\circledR}$ processes developed by Kobe Steel and is based on the rotary hearth furnace. The fundamental difference between ITmk3 and other rotary hearth furnaces, is that the furnace is run between $1400-1450{ }^{\circ} \mathrm{C}$ and through management of slag chemistry, rapid in-situ smelting of iron and generation of a liquid slag occurs. This is a vast departure from the purely solid-state reduction that takes place within FASTMET $^{\circledR}$ and the result is nuggets of gangue free pig iron and a wholly separate slag that is mechanically separable.

There has only been one commercially operating ITmk3 plant worldwide, in Hoyt Lakes, MN (USA) through a joint venture between Kobe Steel and Steel Dynamics. This 500 kt per annum plant began operation in 2010 but is under a long-term mothballing as of this articles writing (Lehtinen 2003). The Hoyt Lakes plant, known as Mesabi Nugget, was based upon the commercial principal of producing a high value-added iron product at close proximity to the mining site. This provides obvious logistical advantages as the iron nuggets produced are around $50 \%$ lighter and $90 \%$ more compact than the equivalent ferrous load in ore. As shown in Table 7, these iron nuggets are chemically very similar to blast furnace pig iron and were successfully used to displace scrap in electric arc furnaces (Kikuchi 2010).

\section{Table 7}

Comparison of ITmk3 pig iron nuggets (Lehtinen 2003) versus BF pig iron. 


\begin{tabular}{lllllll}
\hline Material & $\mathrm{C}(\mathrm{wt} \%)$ & $\mathrm{Si}(\mathrm{wt} \%)$ & $\mathrm{Mn}(\mathrm{wt} \%)$ & $\mathrm{S}(\mathrm{wt} \%)$ & $\mathrm{P}(\mathrm{wt} \%)$ & $\mathrm{Fe}_{\text {Tot }}$ \\
\hline Iron nugget & $2.5-4.3$ & 0.2 & 0.1 & 0.015 & 0.06 & Bal. \\
BF pig iron & 4.76 & 0.58 & 0.3 & 0.005 & 0.08 & Bal. \\
\hline
\end{tabular}

The ITmk3 process was developed for use on iron ore but the RHF reactors ability to handle material that contains high quantities of volatile metals such as zinc could mean it is applicable for adding value to steelmaking by-products (Zhang 2013). There would be several advantages to producing pig iron nuggets versus a DRI product, the gangue content in revert DRI is relatively high and as such it is typically recycled to the BF rather than as a scrap replacement in the BOF. Another key advantage of utilizing the by-products of an integrated works for this process is that both the carbon source and iron source are effectively free, as BF and BOS dust respectively could be used. There are also $\mathrm{CO}_{2}$ emission and energy saving advantages for ITmk3, when compared to a small-scale blast furnace, of $38.6 \%$ and $14.3 \%$ per ton of pig iron produced, respectively, (Atsushi 2010). This saving in energy and emissions are afforded by the total combustion in-situ of the process gas; however, the immensely variable chemistry of by-product materials as well as contamination with very high melting point mineral oxides such as $\mathrm{Al}_{2} \mathrm{O}_{3}$ could render an ITmk3 process unfeasible for the recovery of iron from BOS dust.

The optimal size of an ITmk3 plant in terms of benefitting from economies of scale appears to be around $500 \mathrm{kt}$ per annum. This is a very large volume with regards to steelmaking dust production considering a $10 \mathrm{mt}$ per annum integrated steelworks would produce approximately $200 \mathrm{kt}$ total BF and BOS dust annually. This lack of supply of ferrous material at a single site for the process could be mitigated through centralizing a large ITmk3 unit in a steel production intensive region such as China's Hebei province where a great deal of BOS and BF dust is generated in proximity. On the other hand, western countries where the steel industry has declined substantially, such as the United Kingdom, has left a legacy of large stockpiles of these materials which were simply unable to be economically recovered. The exact quantity of material in these stockpiles is not accurately known but is estimated to be extensive 
(MacKillop 2009). Accurate quantification of a region's ferrous assets locked away in these stockpiles will be critical for assessing the feasibility of any zinc separation technology.

\subsection{Hi-QIP}

The high-quality iron pebble process (Hi-QIP) is chemically speaking very similar to ITmk3, in that it involves direct smelting of iron to generate so called 'pebbles' of iron and a separate slag phase. The key difference, however, is in Hi-QIPs use of a non-agglomerated iron feed material mixed with fluxes and a reducing agent, contained within hollows that are depressed mechanically into a carbonaceous bed on the furnace. This carbon layer has four key functions; the hearth is protected from direct contact with aggressive molten slags, the thermal load on the refractories is lessened, and it acts as an auxiliary reducing agent. Finally, it also determines the geometry of the iron pebbles through control of the size of the hollows. The primary reactor in the Hi-QIP is also a rotary hearth furnace, heated to around $1500{ }^{\circ} \mathrm{C}$ with a residence time of 15-20 minutes. Critically, Hi-QIP has previously been deemed suitable for the processing of BF dusts at an integrated works (Sawa 2001).

A pilot plant operated in Japan in the early 2000's with reasonable results and capacity of $15 \mathrm{tpd}$. The chemistry of the produced iron pebbles is shown in Table 8. They are very chemically similar to ITmk3 pig iron nuggets as well as blast furnace pig, but the sulfur level would be a cause for concern for reintroduction to the BOF (Sawa 2008). It is likely this high sulfur level is the result of reductant selection. The coal used in the study was $0.54 \mathrm{wt} \%$ sulfur with the intimate contact between the carbonaceous bed and liquid iron causing sulfurization of the hot metal.

\section{Table 8}

Chemical analysis of Hi-QIP iron pebbles (Sawa 2008).

\begin{tabular}{lllllll} 
Material & $\mathrm{C}(\mathrm{wt} \%)$ & $\mathrm{Si}(\mathrm{wt} \%)$ & $\mathrm{Mn}(\mathrm{wt} \%)$ & $\mathrm{S}(\mathrm{wt} \%)$ & $\mathrm{P}(\mathrm{wt} \%)$ & $\mathrm{Fe}_{\mathrm{Tot}}$ \\
\hline Hi-QIP Pebbles & $2.1-3.0$ & 0.08 & 0.01 & 0.25 & 0.04 & Balance \\
\hline
\end{tabular}


Table 9 shows the chemical analysis of the BF dust used in comparison to the iron pebbles produced (Sawa 2001). Zn removal was exceptional, with the residual levels of zinc within the iron produced being below the detection limit of the analysis used. This is obviously very promising for the Hi-QIP processes application in managing iron bearing wastes from an integrated works, but more research must be undertaken to reduce the sulfur and phosphorous residual levels within the metal as they would likely render the iron product produced from byproduct materials totally unusable as a scrap replacement in the BOS process, which is very sensitive to input sulfur levels.

\section{Table 9}

Chemical composition $(\mathrm{Wt} \%)$ of the $\mathrm{BF}$ dust alongside iron pebbles produced at $1550{ }^{\circ} \mathrm{C}$ for 555 seconds (Sawa 2001).

Composition (wt\%)

\begin{tabular}{|c|c|c|c|c|c|c|c|c|c|c|c|c|c|c|}
\hline Material & $\mathrm{C}$ & $\mathrm{Fe}_{\text {Total }}$ & $\mathrm{Zn}$ & $\mathrm{Pb}$ & $\mathrm{Na}$ & $\mathrm{K}$ & $\mathrm{Cl}$ & $\mathrm{SiO}_{2}$ & $\mathrm{Al}_{2} \mathrm{O}_{3}$ & $\mathrm{CaO}$ & $\mathrm{MgO}$ & $\mathrm{Mn}$ & $\mathrm{P}$ & $\mathrm{S}$ \\
\hline BF dust & 21.3 & 42.9 & 2.54 & 0.64 & 0.11 & 1.2 & 1.13 & 5.67 & 3.25 & 3.12 & 0.37 & 0.26 & 0.07 & 0.91 \\
\hline Slag & - & 5.8 & 0.02 & - & - & - & - & 34.0 & 18.2 & 34.3 & 3.42 & 0.92 & - & - \\
\hline Iron pebble & 0.93 & Bal. & $<0.01$ & $<0.01$ & - & - & - & - & - & - & - & 0.02 & 0.13 & 0.72 \\
\hline Off-gas & 0.68 & 6.66 & 47.1 & 7.02 & 0.22 & 1.95 & 13.2 & 0.20 & - & - & - & - & - & 2.34 \\
\hline dust & & & & & & & & & & & & & & \\
\hline
\end{tabular}

Unfortunately, there are other drawbacks to the Hi-QIP process relating to the nonagglomeration of the furnace burden. The levels of iron in the collected zinc bearing secondary dust in the process are high (6.66 wt.\%) which may be unacceptable to zinc smelters without further refinement. An agglomerated bed also has poor gas permeability and heat transfer properties, which may offset any productivity bonuses given through denser hearth loading. There is also the potential for yield losses within Hi-QIP due to the separation stage, through solution loss of iron as $\mathrm{FeO}$ into the molten slag phase; however, this can be mitigated through increased hold times and reductant levels and iron yields of 97\% were shown to be achievable (Ishiwata 2009). 
Reduction temperatures in Hi-QIP are very high $\left(1550{ }^{\circ} \mathrm{C}\right)$, even compared to the relatively high temperature $\operatorname{ITmk} 3\left(1450{ }^{\circ} \mathrm{C}\right)$ process. This will obviously have implications on the operational costs of the plant, but the exceptional zinc removal and high value ferrous product may still prove attractive for reintegration of zinc bearing wastes to the iron material cycle.

\subsection{COMET process}

The COMET process is another variant on the RHF process developed by the Centre for Research in Metallurgy (CRM), utilizing a non-agglomerated iron ore mixture in alternating layers with a reducing agent and a desulfurizing agent such as limestone (Steffen \& Lüngen 2004).

Process temperatures in the COMET process are similar to those in INMETCO and FASTMET $^{\circledR}$, but typically residence times are higher and productivity therefore lower, in the former, due to the non-agglomeration of the feed. Following the reduction step, DRI is formed in a sheet of about $10 \mathrm{~mm}$ in thickness (relating to the thickness of the ore layer in the original charge), which is broken apart and screened from the other discrete layers. The nonagglomeration provides a few key process advantages, which may make it attractive. Firstly, the removal of the pelletization step removes an element of operational cost from the plant as well as removing the need for a binder. Secondly, the discrete layers allow for the inclusion of a desulfurizing agent such as limestone, which is separable from the DRI product. As a result, sulfur concentration in Sidcomet DRI are usually very low, and less dependent on reductant selection. This is an advantage for sulfur sensitive DRI end uses such as BOF or EAF steelmaking. The lack of intimate contact between the carbon and iron layers also reduces the overall level of gangue within the direct reduced iron, as coal ash is not introduced into the material.

Table 10 shows typical chemical analysis for COMET DRI produced from virgin ore. COMET DRI is clearly of a superior quality to other coal based RHF processes in terms of sulfur and gangue content, but this advantage comes at a productivity cost, the material in the 
COMET process has a residence time of approximately 80 minutes, whereas FASTMET $^{\circledR}$ operates at around a 12 minute residence time (Holappa 2000).

COMET is also suitable for processing zinc and lead bearing by-products and the reducing agent layer is also suitable for recycling in an integrated steelworks through a sinter plant. The COMET process has yet to be scaled to commercial operation, it seems unlikely that the benefits of lower sulfur and gangue content in the DRI product, and the lack of an agglomeration stage is substantial enough to offset the reduction in productivity.

\section{Table 10}

Typical analysis of COMET DRI (Chatterjee 2012).

\begin{tabular}{llllll} 
Material & $\mathrm{C}(\mathrm{wt} \%)$ & $\mathrm{SiO}_{2}(\mathrm{wt} \%)$ & $\mathrm{S}(\mathrm{wt} \%)$ & $\mathrm{Fe}_{\mathrm{Tot}}(\mathrm{wt} \%)$ & $\mathrm{Fe}_{\mathrm{Met}}(\mathrm{wt} \%)$ \\
\hline COMET DRI & 0.2 & 1.86 & 0.032 & 95.8 & 88.1 \\
\hline
\end{tabular}

\section{Zinc recovery focused pyrometallurgical extraction processes}

All of the above-mentioned processes have focused principally on the removal of zinc from an iron product to allow for the iron to be recovered through steelmaking. As such, zinc in every process discussed thus far is recovered as a crude $\mathrm{ZnO}$, usually slightly contaminated by iron dust. This section highlights technologies designed to produce metallic $\mathrm{Zn}$ as a primary product.

Due to the much higher zinc content of EAF dust compared with BOS dust, most of this research on value generation from producing metallic zinc took place on EAF dust; however, the data provides insight to applicability for BOS dust. Electrothermic processes based on traditional zinc extraction from ore are a commercial reality, however, they typically consist of repurposed facilities retrofitted to handle steelmaking dusts. Due to the low zinc content of steelmaking dusts relative to virgin zinc ores and the capital outlay to set up and maintain them, it is highly unlikely that these types of processes will expand into BOS dust recycling. Typically, these processes are characterized by very high process costs either due to their discontinuous nature, high electricity requirements or complex design.

The Laclede Steel process effectively utilized a modified, electric arc furnace to reduce and volatize $\mathrm{Zn}$ from EAF dust. However, what made the process innovative was the inclusion 
of a splash condenser to capture metallic zinc from the process gas rather than allowing oxidation of the Zn product (Zunkel 1996). The benefit of this is that a lead splash condenser can co-produce lead bullion, and lead is a major contaminant in EAF dust. Yet the process was pained by production problems in relation to the quality of zinc produced, it was not deemed high enough for hot dip galvanizing use internally as intended. Laclede Steel was liquidated in 2002 amidst difficult economic steelmaking conditions.

The Mintek Enviroplas process (Schoukens 1993) utilizes a DC arc furnace to produce a metallic $\mathrm{Zn}$ product through the condensation of $\mathrm{Zn}$ vapor in a lead splash condenser, but the extremely fine nature of the dust particles processed can cause issues with splash condenser efficiency (Assis 1998).

A hybridized RHF/electrical furnace plant was built in Arkansas (USA) by AllMet around 1998. This plant utilized a standard RHF configuration with crude oxide produced being re-fumed in an electric furnace and condensed using a molten zinc splash condenser but was found to be untenable - the splash condenser was never truly operational and the quality of DRI produced was poor (Southwick 2010).

The Horsehead Resource Development Co., Inc. patented a hydrocarbon-fuelled cyclone melting system for treatment of high zinc dusts (Keegel 1996) and a 30,000 t/year plant was established in Texas in 1993. The plant involved injecting fine, dried steelmaking dusts with oxygen enriched air and hydrocarbon fuel into a cyclonic reactor. Reduction of volatiles such as zinc and lead would occur giving a crude $\mathrm{Zn}$ oxide product and a ferrous slag.

The Ausmelt process is a two-stage furnace process, involving a smelting vessel and a reduction vessel. Dusts and lump coal are charged to the furnace and enriched air and powdered reductants are inputted through a cooled lance. $\mathrm{ZnO}$ fumes out of the melt and is collected for sale (Assis 1998).

The iron bearing dust recovery-zinc iron plasma process (IBDR-ZIPP) is another crude oxide producing zinc recovery process. Pelletized dusts and reductants are charged into a furnace where two electrodes generate a high voltage arc. This forms a plasma, which forces the reduction of the raw materials. This process is differentiated from many of the other crude oxide generating processes by the fact it forms molten pig iron suitable for charging directly to 
a BOS vessel. The IBDR-ZIPP process is energy and capital intensive but produces a stable slag, a useable iron product in the form of pig iron and a saleable zinc oxide meaning no further by-product processing is required within the steelmaking operation prior to sale.

\section{Next generation ironmaking technology}

The ULCOS (Ultra Low $\mathrm{CO}_{2}$ Steelmaking) project's key technological development in collaboration with Hismelt has been the HIsarna process. This ironmaking technology is a huge paradigm shift from the blast furnace iron production route, and offers numerous potential advantages including dramatic $\mathrm{CO}_{2}$ reductions, high energy efficiency and, most importantly for the discussion in this paper, high raw material flexibility (Meijer, 2013).

Currently undergoing pilot scale testing at Tata Steel IJmuiden in the Netherlands, the operating concept of this technology is a cyclonic reduction section located directly above a final smelting reactor. Fine material and flux are injected in at high speeds to the top of the reactor where it is pre-reduced by the reactive smelter gases and descends via gravity into the final bath smelter.

This process is designed to alleviate the need for environmentally and economically expensive feed preparation for the blast furnace (sintering, coking) as well as take advantage of the excellent mixing and thermal efficiency of the HIsmelt smelter bath technology (Dry, 1999). The product of the HIsarna process is hot metal, chemically comparable to that produced via the blast furnace. Typical hot metal chemistry of HIsarna iron from the pilot plant in the Netherlands is shown in Table 11.

\section{Table 11}

Typical analysis of HIsarna iron (Dry, 1999).

Elemental Composition ( $\mathrm{wt} \%$ )

\begin{tabular}{|c|c|c|c|c|c|c|c|c|}
\hline & $\mathrm{C}$ & $\mathrm{S}$ & $\mathrm{Cr}$ & $\mathrm{P}$ & $\mathrm{Mn}$ & $\mathrm{V}$ & $\mathrm{Si}$ & $\mathrm{Ti}$ \\
\hline HIsarna & $3.7-4.3$ & $0.1-0.2$ & $0.03-$ & $0.02-$ & $0.02-$ & $0.05-$ & $0.003-$ & $0.0-$ \\
\hline Iron & & & 0.10 & 0.06 & 0.05 & 0.013 & 0.013 & 0.002 \\
\hline
\end{tabular}


HIsarna based reactors are not as sensitive to zinc loading as a blast furnace, and a $\mathrm{Zn}$ rich dust fraction is produced within the cyclonic section of the reactor. It may therefore be feasible to reintegrate high zinc dusts into a HIsarna based ironmaking process to enrich the zinc content to an extent whereby they become attractive raw materials for zinc recyclers.

The inclusion of high zinc materials such as BOS dust, EAF dust and BF dust into the HIsarna furnace burden has been studied (Peters, 2019) and appears promising. The extremely high temperatures in the cyclonic reactor portion of the plant combined with the reducing atmosphere means that multi-stage enrichment of zinc in HIsarna flue dust may be able to create a dust fraction high enough in $\mathrm{Zn}$ for direct sale to zinc processors.

\section{Further Processing of the Crude Zinc Oxide Product}

The product of almost every process described in this review is crude zinc oxide powder, which is extracted from the off-gas system of the heat treatment unit. The exceptions to this such as Enviroplas, which utilize a liquid zinc condenser system to recover zinc in the metallic form. Theoretically, an Enviroplas plant would be able to sell recovered zinc with minimal further processing to zinc end users. However, these condensers are not currently operated on a large scale and as the product requires almost no post processing, attention should instead be paid to the $\mathrm{ZnO}$ product from RHF and Waelz Kiln based processes. This zinc rich dust generated from most of the technology discussed here is usually referred to as a 'Waelz Oxide' and is recyclable through two major pathways; The Imperial Smelting Furnace (ISF), which is in effect a zinc producing blast furnace (Morgan, 1968), and electrolytic zinc production which is by far the dominant production pathway with around $90 \%$ of zinc produced globally being produced electrolytically (Antuñano 2019).

The primary concern with regard to Waelz oxides recycling into an electrolytic process comes from contamination of the oxide with halides, such as $\mathrm{Cl}$ and $\mathrm{F}$. Halide contamination can cause rapid deterioration of electrodes and introduce impurities into the final metallic zinc during processing (Wu, 2014). Several processes have been developed that are capable of dealing with the high levels of halide impurities found in Waelz Oxide including the Modified 
Zincex ${ }^{\circledR}$ Process (Diaz, 1994) and Zinclor process (Nogueira, 1983). The value of the zinc oxide produced must be factored into determining the economics of separating zinc from BOS dust, one key advantage that the RHF has over the Waelz kiln is that without the tumbling action of the burden inside a Waelz kiln, mechanical ejection of iron oxide material into the off-gas system is limited and hence the value of the Waelz oxide produced is greater.

\section{Conclusions}

The reintegration of zinc bearing by-products of steelmaking persists as a key materials efficiency and environmental issue for steel manufacturers. BOS dust in particular presents a challenge as the zinc content renders it unable to be effectively 'diluted out' through reintroduction to existing $\mathrm{BF} / \mathrm{BOS}$ processing but the value of the zinc content is substantially less than in EAF dust meaning many existing processes use to passivate and/or generate value from EAF dust are not commercially viable for the integrated works.

The key commercial drivers for an integrate steelworks with regards to processing this $\mathrm{Zn}$ bearing material are;

- High zinc removal, allowing full material reintegration into existing processes

- Valorization of iron units present within the material

- High capacity and good economies of scale

The necessity of a high value iron product effectively rules out hydrometallurgical recovery of $\mathrm{Zn}$ as the resulting iron-bearing sludge would be very low, likely to require drying and agglomeration via a sinter plant before iron can be recovered.

The morphology of the dust and its chemical composition have a large impact on the viability of recycling routes. The main influencing factors are described in Table 12. Although the Waelz Kiln has been surpassed by the RHF, as the principal reactor for the removal of zinc from steelmaking by-products, it is unclear which of the current generation of RHF technologies will dominate in the short to medium term, FASTMET $^{\circledR}$ and DRyIron ${ }^{\mathrm{TM}}$ have clear advantages and are readily commercially available and proven technologies. Production unit sizes of around 200-300 kt are ideally sized for managing the BOS dust output from a single plant and can easily feed DRI back into the blast furnace or basic oxygen steelmaking process. 
Table 12

Key influencing properties of BOS dust on recycling process selection

\begin{tabular}{|c|c|}
\hline Property & Comments \\
\hline $\mathrm{Fe}_{\mathrm{Tot}}(\mathrm{wt} \%)$ & $\begin{array}{l}\text { A larger proportion of iron compared to non-ferrous minerals } \\
\text { makes recycling more attractive due to higher throughput and } \\
\text { lower latent heat loss during recycling of the produced DRI in the } \\
\text { ironmaking process. }\end{array}$ \\
\hline $\mathrm{Zn}(\mathrm{wt} \%)$ & $\begin{array}{l}\text { For material }<0.1 \mathrm{Zn} w \mathrm{t} \% \text { recycling through dilution may be } \\
\text { feasible and for very high } \mathrm{Zn} \text { content material }(>20 \mathrm{wt} \%) \\
\text { hydrometallurgical techniques may become commercially viable. }\end{array}$ \\
\hline $\mathrm{ZnO}: \mathrm{ZnFe}_{2} \mathrm{O}_{4}$ & $\begin{array}{l}\text { The proportion of zinc present in the ferrite form is critical when } \\
\text { selecting a recycling route, } \mathrm{ZnFe}_{2} \mathrm{O}_{4} \text { is highly resistant to } \\
\text { hydrometallurgical extraction under realistic industrial conditions. }\end{array}$ \\
\hline $\mathrm{O}_{\mathrm{Fe}}(\mathrm{wt} \%)$ & $\begin{array}{l}\text { The degree of oxidation of iron present within BOS dust is critical } \\
\text { when determining the feasibility of a pyrometallurgical } \mathrm{Zn} \text { process. } \\
\text { The more metallized (and therefore the lower the value of } \mathrm{O}_{\mathrm{Fe}} \text { ) the } \\
\text { lower the requirement for reducing agents in the process and the } \\
\text { shorter the processing time. This leads to a higher Fe } \mathrm{Fe}_{\text {tot }} \text { of process } \\
\text { feed as well as reducing raw material costs. }\end{array}$ \\
\hline $\mathrm{CaO}: \mathrm{SiO}_{2}$ & $\begin{array}{l}\text { This ratio is often referred to as the 'basicity' of the produced DRI } \\
\text { and has major implications for the value in use of the product in } \\
\text { blast furnace/basic oxygen steelmaking production, as well as for } \\
\text { the mechanical strength of the DRI (Chaung et al.). }\end{array}$ \\
\hline $\begin{array}{l}\text { Halide content. F, Cl } \\
(\mathrm{wt} \%)\end{array}$ & $\begin{array}{l}\text { The overall concentration of halides in the material to be recycled } \\
\text { has an effect on the value of the separated zinc product due to its } \\
\text { deleterious effect on electrolytic zinc production }\end{array}$ \\
\hline
\end{tabular}

It seems unlikely that newer steel plants globally will be allowed to operate without a recovery pathway for zinc bearing wastes generated through the process, as legislative pressure to reduce environmental impact and rising landfilling costs render previous disposal routes uneconomical. The fact that RHF technology can utilize other waste products such as the carbon bearing BF dust is another advantage of these reactors, displacing coals with a by-product and thus eliminating BF dusts need for landfilling simultaneously. As high-quality zinc ore deposits become scarcer moving through the $21^{\text {st }}$ century the value of recovered zinc oxides will likely rise, which may make in-situ recovery at a steel plant a more economically attractive option.

The RHF appears set to be the best available technology for the first half of the $21^{\text {st }}$ century, many different variations on this technology have achieved commercial success and 
their ubiquity, the high value in use of the produced Direct Reduced Iron and lower technical complexity than the obsolete Waelz Kiln make them very attractive for an integrated steel plant.

Zinc focused recovery methods such as the Enviroplas process are unlikely to see widespread use in the short to medium term and are much more suitable for processing EAF dust where the high zinc content can be more effectively valorized. This may change in the far future however as cheap renewable energy becomes more readily available, technology that utilizes electrical energy such as IBDR-ZIPP and Enviroplas could become feasible if the value of the recovered zinc can offset their high capital requirements and energy consumption.

High value-added technologies such as Hi-QIP and ITmk3 have not seen commercial use in recovery of volatile metals from by-product material but may in future, depending on economic conditions. Hi-QIP and ITmk3 are less suitable for smaller scale application such as managing the dust produced at a single integrated works but may potentially be viable for larger scale remediations of post-industrial countries where large legacy stockpiles of materials exist and require remediation, such as the United Kingdom.

In terms of removal of zinc and in the metallization of the product, the molten stage processes such as Hi-QIP, ITmk3 etc. are outstanding, able to reduce zinc content in the ferrous output to trace levels and obtaining complete metallization of the residual iron. The drawback however is the increased reaction temperatures required to drive the carburization and melting reactions and the operational costs that they incur.

\section{Table 12}

Summary of advantages and disadvantages of various zinc removal processes.

\begin{tabular}{|c|c|c|c|c|}
\hline Process & Products & Process Description & Advantages & Disadvantages \\
\hline Waelz Kiln & $\begin{array}{l}\text { Waelz } \\
\text { slag, } \mathrm{ZnO}\end{array}$ & $\begin{array}{l}\text { Horizontal rotating } \\
\text { cylinder fed by granular } \\
\text { feed and fired with } \\
\text { natural gas } / \text { coal. } \\
\text { hours at }>1000^{\circ} \mathrm{C}\end{array}$ & $\begin{array}{l}\text { Well established and proven } \\
\text { technology. } \\
\text { No need for pelletization of in- } \\
\text { feed }\end{array}$ & $\begin{array}{l}\text { Low productivity } \\
\text { Low metallization } \\
\text { High Fe content of } \mathrm{ZnO} \\
\text { produced } \\
\text { High maintenance costs }\end{array}$ \\
\hline FASTMET & DRI, ZnO & $\begin{array}{l}\text { RHF fed with pelletized } \\
\text { iron oxides and carbon } \\
\text { source. } 1300^{\circ} \mathrm{C} \text { for } 6-12 \\
\text { minutes }\end{array}$ & $\begin{array}{l}\text { Most established commercial } \\
\text { RHF process } \\
\text { High throughput } \\
\text { DRI useful in blast furnace }\end{array}$ & $\begin{array}{l}\text { DRI has a higher gangue content } \\
\text { than INMETCO etc. }\end{array}$ \\
\hline DryIRon & DRI, $\mathrm{ZnO}$ & $\begin{array}{l}\text { RHF fed with binderless } \\
\text { briquettes. } 1300{ }^{\circ} \mathrm{C} \text { for } \\
\sim 15 \text { minutes }\end{array}$ & $\begin{array}{l}\text { No need for expensive binder. } \\
\text { High metallization } \%\end{array}$ & $\begin{array}{l}\text { No binder means unfired } \\
\text { briquettes are extremely fragile } \\
\text { Not as established as Fastmet }\end{array}$ \\
\hline
\end{tabular}




\begin{tabular}{|c|c|c|c|c|}
\hline ITmk3 & $\begin{array}{l}\text { Pig Iron } \\
\text { Nuggets }\end{array}$ & $\begin{array}{l}\text { RHF fed with pellets, } \\
1450{ }^{\circ} \mathrm{C} \text { for } 10-20 \\
\text { minutes }\end{array}$ & $\begin{array}{l}\text { Complete metallization and slag } \\
\text { separation } \\
\text { Rapid reaction speeds } \\
\text { Extremely high value product }\end{array}$ & $\begin{array}{l}\text { High refractory and energy } \\
\text { operational expenditure } \\
\text { Untested for } \mathrm{Zn} \text { recovery from } \\
\text { by-products } \\
\text { Only one commercial plant that } \\
\text { no longer operates }\end{array}$ \\
\hline INMETCO & $\begin{array}{l}\text { Direct } \\
\text { Reduced } \\
\text { Iron, } \mathrm{ZnO}\end{array}$ & $\begin{array}{l}\text { Pelletized feed charged } \\
\text { in } 3 \text { layers to an RHF. } \\
1300{ }^{\circ} \mathrm{C} \text { for }>60 \text { min. } \\
\text { Can be supplemented } \\
\text { with a submerged arc } \\
\text { furnace melter }\end{array}$ & $\begin{array}{l}\text { Proven technology, industrial } \\
\text { plant operating } \\
\text { Supplementing with melter unit } \\
\text { can increase thermal efficiency } \\
\text { by utilizing latent heat of } \\
\text { process DRI }\end{array}$ & $\begin{array}{l}\text { Long residence time and low } \\
\text { throughput } \\
\text { Layered structure leads to non- } \\
\text { homogeneity of DRI } \\
\text { Melter units are energy } \\
\text { intensive }\end{array}$ \\
\hline COMET & $\begin{array}{l}\text { Direct } \\
\text { reduced } \\
\text { iron, } \mathrm{ZnO}\end{array}$ & $\begin{array}{l}\text { Non-agglomerated feed } \\
\text { charged to an RHF and } \\
\text { fired for }>60 \text { min at } \\
1300{ }^{\circ} \mathrm{C} \text {. Can be } \\
\text { supplemented with a } \\
\text { submerged arc furnace } \\
\text { melter }\end{array}$ & $\begin{array}{l}\text { Addition of limestone layer can } \\
\text { give very low sulfur DRI } \\
\text { No pelletization required. } \\
\text { Can be fueled by coke oven gas. } \\
\text { Can produce hot metal with } \\
\text { addition of submerged arc } \\
\text { furnace. }\end{array}$ & $\begin{array}{l}\text { Low productivity per sq metre } \\
\text { of hearth } \\
\text { Limited DRI strength } \\
\text { Melter units are energy } \\
\text { intensive }\end{array}$ \\
\hline Hi-QIP & $\begin{array}{l}\text { Pig Iron } \\
\text { Nuggets, } \\
\mathrm{ZnO}\end{array}$ & $\begin{array}{l}\text { Powder feed charged } \\
\text { onto a carbon bed within } \\
\text { an RHF fired to } 1500{ }^{\circ} \mathrm{C} \\
\text { for } 10-20 \text { min. Total } \\
\text { separation of Fe and slag } \\
\text { occurs }\end{array}$ & $\begin{array}{l}\text { High value pig iron product } \\
\text { Rapid reaction speed } \\
\text { Zinc removal has been } \\
\text { previously explored using Hi- } \\
\text { QIP }\end{array}$ & $\begin{array}{l}\text { Very high temperature requires } \\
\text { expensive refractories and high } \\
\text { energy costs } \\
\text { Not commercially implemented } \\
\text { Requires auxiliary carbon } \\
\text { source }\end{array}$ \\
\hline $\begin{array}{l}\text { Laclede } \\
\text { Steel } \\
\text { Process }\end{array}$ & $\begin{array}{l}\text { Hot metal, } \\
\text { metallic } \\
\text { Zn, lead } \\
\text { bullion }\end{array}$ & $\begin{array}{l}\text { A modified EAF } \\
\text { zinc/lead }\end{array}$ & $\begin{array}{l}\text { Ind lead } \\
\text { lucts }\end{array}$ & $\begin{array}{l}\text { Very high capital investment } \\
\text { and operational costs } \\
\text { More suited for EAF dust } \\
\text { processing }\end{array}$ \\
\hline Enviroplas & $\begin{array}{l}\text { Stabilized } \\
\text { slag, } \\
\text { metallic } \\
\text { Zn }\end{array}$ & $\begin{array}{l}\text { DC arc furnace with } \\
\text { splash condenser }\end{array}$ & High value metallic zinc product & $\begin{array}{l}\text { Low value ferrous product } \\
\text { More suitable for passivated } \\
\text { hazardous EAF dusts than BOS } \\
\text { dust }\end{array}$ \\
\hline Ausmelt & $\begin{array}{l}\text { Stabilised } \\
\text { slag, } \mathrm{ZnO}\end{array}$ & $\begin{array}{l}\text { Two stage smelting } \\
\text { reduction reactor }\end{array}$ & $\begin{array}{l}\text { Small process footprint } \\
\text { Not electrically powered }\end{array}$ & $\begin{array}{l}\text { Low value ferrous product. } \\
\text { Only economical for high zinc } \\
\text { wastes }\end{array}$ \\
\hline $\begin{array}{l}\text { IBDR- } \\
\text { ZIPP }\end{array}$ & $\begin{array}{l}\mathrm{ZnO} \text {, hot } \\
\text { metal, slag }\end{array}$ & $\begin{array}{l}\text { Agglomerated feed of } \\
\text { material to a plasma } \\
\text { heated reduction } \\
\text { smelting reactor }\end{array}$ & $\begin{array}{l}\text { High value products which can } \\
\text { be used within the steel plant }\end{array}$ & $\begin{array}{l}\text { Very high expenses and capital } \\
\text { cost } \\
\text { Only economical for high zinc } \\
\text { wastes }\end{array}$ \\
\hline
\end{tabular}

It is to be expected that the price of zinc will rise as global high-quality virgin ore reserves dwindle and demand for galvanized steel increases and thus the processing of lower zinc ferrous by-products will become more economically favorable as it has with the higher zinc EAF dusts. As such, the lower boundary of $\mathrm{Zn}$ wt.\% in dusts that can be economically processed is likely to fall in time. Legislative pressure may also have an impact, as landfilling fees are also likely to rise in developed countries, making recycling more commercially attractive. For the iron producer production of a reduced iron product from these by-products also has the economic incentive of displacing expensive reducing agents and iron units in further iron production. Ultimately, the next generation of ironmaking technology, processes such as HISarna will need to alleviate the tight raw material requirements of the blast furnace 
and allow for high Zn materials to be processed without pre-treatment. The steel industry must overcome these barriers to the circular usage of galvanized steel if it is to become truly sustainable.

\section{Acknowledgments}

Financial support was provided by Materials and Manufacturing Academy (M2A) that has been made possible through funding from the European Social Fund via the Welsh Government, the Engineering and Physical Sciences Research Council (EPSRC), and Tata Steel. Additional support is provided by the Reducing Industrial Carbon Emissions (RICE) operations funded by the Welsh European Funding Office (WEFO) through the Welsh Government.

\section{References}

Adams, W., Dirlam, J. B., 1966. Big steel, invention and innovation, Q. J. Econ. 80 (2), 167189. DOI:10.2307/1880688.

Ahmed, H., 2018. New trends in the application of carbon-bearing materials in blast furnace iron-making. Minerals 8 (12), 561. DOI:10.3390/min8120561.

Allwood, J., Cullen, J. M., Milford, R. L., 2010. Options for achieving a 50\% cut in industrial carbon emissions by 2050. Environ. Sci. Technol. 44 (6), 1888-1894. DOI:10.1021/es902909k.

Anameric, B., Kawatra, K., 2007. Properties and features of direct reduced iron. Min. Proc. Ext. Met. Rev. 28 (1), 59-116. DOI:10.1080/08827500600835576.

Antuñano, N., Cambra, J. F., Arias, P.L. 2019. Hydrometallurgical processes for Waelz oxide valorisaton - an overview, Process Safety and Environmental Protection. 129, 308-320 DOI: 10.1016/j.psep.2019.06.028

Assis, G., 1998. Emerging pyrometallurgical processes for zinc and lead recovery from zincbearing waste materials. Zinc and Lead Processing Symposium, The Metallurgiccal Society of CIM, Calgary, Canada, August 1998. Paper 8423.

Atsushi, M., Uemura, H., Sakaguchi, T. 2010. MIDREX processes, Kobelco Technol. Rev. 29 
(12), 50-57.

Bragg, W. H., 1915. The structure of magnetite and the spinels, Nature, 95 (7), 561-561. DOI:10.1038/095561a0.

Brandt, D. A., Warner, J, C., 2005. Metallurgy Fundamentals. Goodheart-Wilcox, Tinley Park, IL. ISBN:1605250805.

Cantarino, M. V., De Carvalho Filho, C., Borges Mansur, M., 2012. Selective removal of zinc from basic oxygen furnace sludges. Hydrometallurgy 111-112 (1), 124-128. DOI:10.1016/j.hydromet.2011.11.004.

Chatterjee, A., 2012. Sponge iron production by direct reduction of iron oxide, PHI Private Learning Limited, $2^{\text {nd }}$ Ed. Delhi, India. ASIN:B00K7BMK1Y.

Daigo, I., Osako, S., Adachi, Y., Matsuno, Y., 2014. Time-series analysis of global zinc demand associated with steel. Resour. Conserv. Recy. 82 (1), 35-40. DOI:10.1016/j.resconrec.2013.10.013.

Diaz, G., Martin, D., 1994, Modified Zincex Process: the clean, safe and profitable solution to the zinc secondaries treatment. Resources, Conservation and Recycling 10 (1-2), 43-57. DOI: 10.1016/0921-3449(94)90037-X.

Dry, R.J., Bates, C.P., Price, D.P., 1999. HIsmelt - the future in direct ironmaking. Ironmaking Conference, 58. 361-366. ISBN: 1-886362-32-7.

Dutra, A. J. B., Paiva, P. R. P., Tavares, L. M., 2006. Alkaline leaching of zinc from electric arc furnace steel dust. Miner. Eng. 19 (5), 478-485. DOI:10.1016/j.mineng.2005.08.013.

Espinosa, D. C. R., Bernardes, A. M., Alberto, J., Tenório, S., 2004. An overview on the current processes for the recycling of batteries. J. Power Sources 135 (1-2), 311-319. DOI:10.1016/j.jpowsour.2004.03.083.

Fisher, L. V., Barron, A. R., 2019. The recycling and reuse of steelmaking slags- a review. 146 (7), 244-255. DOI:10.1016/j.resconrec.2019.03.010.

Fruehan, R. J., 2005. New steelmaking processes: drivers, requirements and potential impact, Ironmaking \& Steelmaking, 32:1, 3-8, DOI: 10.1179/irs.2005.32.1.3

Gargul, K., Boryczko, B., 2015. Removal of zinc from dusts and sludges from basic oxygen furnaces in the process of ammoniacal leaching. Arch. Civ. Mech. Eng. 15 (1), 179-187. 
DOI:10.1016/j.acme.2014.08.004.

Gargul, K., Jarosz, P., Małecki, S., 2016. Alkaline leaching of low zinc content iron-bearing sludges. Arch. Metall. Mater. 61 (1), 43-50. DOI:10.1515/amm-2016-0013.

Gielen, D., Moriguchi, Y., 2002. $\mathrm{CO}_{2}$ in the iron and steel industry: an analysis of Japanese emission reduction potentials. Energy Policy 30 (10), 849-863. DOI:10.1016/S03014215(01)00143-4.

Goetz, F., 1980. The Mechanism of B.O.F. Fume Formation. Thesis, MEng. McMaster University.

Gritzan, XX., Neuschütz, D., 2001. Rates and mechanisms of dust generation in oxygen steelmaking. Steel Res. 72 (9), 324-330. DOI:10.1002/srin.200100126.

Hahn, I., Neuschütz, D., 2002. Ejection of steel and slag droplets from gas stirred steel melts. Ironmak. Steelmak. 29 (3), 219-223. DOI:10.1179/030192302225004115.

Hanewald, R. H., Munson, W. A., Schweyer, D. L., 1992. Processing steel wastes pyrometallurgically at INMETCO, Mining, Metall. Explor. 9 (4), 169-173. DOI: 10.1007/BF03403430

Hay, S. M., Rankin, W. J., 1994. Recovery of iron and zinc from blast furnace and basic oxygen furnace dusts: A thermodynamic evaluation. Miner. Eng. 7 (8), 985-1001. DOI:10.1016/0892-6875(94)90028-0.

Henschen, H. C., 1968. Wet vs dry gas cleaning in the steel industry, 18 (5), 338-342. DOI:10.1080/00022470.1968.10469138.

Heinrich, T., 2015. Thesis, PhD. Cardiff University.

Holappa, L. E., Kekkonen, M., 2000. Comparison of different coal based direct reduction processes. Technical Report, Helsinki Univ. of Technology, Otaniemi (Finland). Materials Science and Metallurgy. ISBN:951-22-5134-5.

Hoskins, B. J., Draghici, I., Davies, H. C., 1966. A new look at the cause of fuming, JOM 18 (7), 803-810. DOI:10.1007/BF03378469.

HRDC, Horsehead Resource Development Co., Inc. Flame Reactor Technology Description, https://clu-in.org/products/site/complete/democomp/horseres.htm (accessed 24 September 2019) 
Ishiwata, N., Sawa, Y., Hiroha, H., Matsui, T., Murao, A., Higuchi, T., Takeda, K. 2009. Investigation of reduction and smelting mechanism in the Hi-QIP process. Steel Res. Int. 80 (8), 523-529. DOI:10.2374/SRI09SP040.

Jaafar, I., 2014. Chlorination for the removal of zinc from basic oxygen steelmaking (BOS) byproduct. Thesis, PhD. Cardiff University.

Keegel, Jr, J. F., 1996. Methods for recycling electric arc furnace dust. US Patent 5,538,532.

Kelebek, S., Yörük, S., Davis, B., 2004. Characterization of basic oxygen furnace dust and zinc removal by acid leaching. Miner. Eng. $17 \quad$ (2), 285-291. DOI:10.1016/j.mineng.2003.10.030.

Kikuchi, S., Ito, S., Kobayashi, I., Tsuge, O., Tokuda, O., 2010. Midrex Technologies, ITmk3 process, Kobelco Technol. Rev. 29, 69-77.

Kim, Y., Worrell, E., 2002. International comparison of $\mathrm{CO}_{2}$ emission trends in the iron and steel industry. Energy Policy 30 (10), 827-838. DOI:10.1016/S0301-4215(01)00130-6.

Kobe Steel 1td, World's first commercial ITmk3 plant successfully begins production, http://www.kobelco.co.jp/english/releases/2010/1182907_14776.html, (accessed 29 May 2018).

Kobelco, Fastmet ${ }^{\circledR}$ Process, http://www.kobelco.co.jp/english/products/fastmet/, (accessed 20 May 2019).

Kohlmeyer, E., Spandau, H., 1944. Ueber die Vergasung von Eisen. Arch. Eisenhüttenwes 18 (1), 1-6. DOI:10.1002/srin.194401336.

Krishnamurthy, K. R., Gopalakrishnan, J., Aravamudan, G., Sastri, M. V. C., 1974. Studies on the formation of zinc ferrite. J. Inorg. Nucl. Chem. 36 (3), 569-573. DOI:10.1016/00221902(74)80115-6.

Kuzmann, E., Nagy, S., Vértes, A., 2003. Critical review of analytical applications of Mössbauer spectroscopy illustrated by mineralogical and geological examples (IUPAC Technical Report). Pure Appl. Chem. 75 (6), 801-858. DOI:10.1351/pac200375060801.

Lee, J., Lin, C., Chen, H., 2001. Carbothermal reduction of zinc ferrite. Metall and Materi Trans B 32, 1033-1040. DOI: https://doi.org/10.1007/s11663-001-0092-9

Lehtinen, L. 2003. The Mesabi Nugget Project: New Ironmaking technology of the future. 
Direct from MIDREX Q2 3-8.

Lin, X., Peng, Z., Yan, J., Li, Z., Hwang, J.-Y., Zhang, Y., Li, G., Jiang, T., 2017. Pyrometallurgical recycling of electric arc furnace dust. J. Clean. Prod. 149 (4), 1079-1100. DOI:10.1016/j.jclepro.2017.02.128.

Lin, B., Wang, X., 2015. Carbon emissions from energy intensive industry in China: Evidence from the iron \& steel industry. Renew. Sust. Energ. Rev. 47 (7), 746-754. DOI:10.1016/j.rser.2015.03.056.

Liu, S., Loper, Jr., C. R., 1991. The formation of kish graphite, Carbon 29 (4-5), 547-555. DOI:10.1016/0008-6223(91)90119-4.

Lobato, N. C. C., Villegas, E. A., Mansur, M. B., 2015. Management of solid wastes from steelmaking and galvanizing processes: A brief review. Resour. Conserv. Recy. 102 (9), 4957. DOI:10.1016/j.resconrec.2015.05.025.

Lu, L., Pan, J. Zhu, D. in Iron Ore, Chapter 16. Quality requirements of iron ore for iron production, Elsevier, 2015. ISBN: 9781782421566

Ma, N., 2016. Recycling of basic oxygen furnace steelmaking dust by in-process separation of zinc from the dust. J. Clean. Prod. 112 (5), 4497-4504. DOI:10.1016/j.jclepro.2015.07.009.

MacKillop, F., 2009. The construction of 'waste' in the UK steel industry. J. Environ. Plan. Manag. 52 (2), 177-194. DOI:10.1080/09640560802666529.

Mager, K. , Meurer, U. , Garcia-Egocheaga, B. , Goicoechea, N. , Rutten, J., Saage, W. and Simonetti, F. (2013). Recovery of zinc oxide from secondary raw materials: new developments of the waelz process. In Recycling of Metals and Engineered Materials (eds D. L. Stewart, J. C. Daley and R. L. Stephens). DOI:10.1002/9781118788073.ch29

Masson, N., Briol, P., 1969. A brief summary of zinc oxide processing methods available for the Bongará deposit. Zinc One Resources Inc.

Mikhail, S. A., Turcotte, A.-M., 1998. Thermal reduction of steel-making secondary materials: I. Basic-oxygen-furnace dust. Thermochim. Acta 311 (1-2), 113-119. DOI:10.1016/S00406031(97)00430-9.

Money, K. L., Hanewald, R. H., Bleakney, R. R., 2000. Processing steel waste pyrometallurgically at INMETCO. Recycling of Metals and Engineered Materials, Ed. 
Steart, D. L., Stephens, R., Daley, J. C., The Minerals, Metals \& Materials Society, Warrendale, PA, 397-408. ISBN:0-87339-49-1.

Morgan, S. W. K., Greenwood, D. A., 1968. The metallurgical and economic behavior of lead in the imperial smelting furnace. JOM. 20 (12), 31-35. DOI: 10.1007/BF03378767

Narita, K., Onoye, T., Satoh, Y., Miyamoto, M., Taniguchi, K., Kamatani, S., Sato, T., Fukihara, S., 1981. Effects of alkalis and zinc on the wear of blast furnace refractories and the tuyere displacement. Trans. Iron Steel Inst. Japan 21 (12), 839-845. DOI:10.2355/isijinternational1966.21.839.

Nedar, L., 1996. Dust formation in a BOF converter. Steel Res. Int. 67 (8), 320-327. DOI:10.1002/srin.199605497.

Nogueira, E. D., Cosmen, P., 1983. The Zinclor Process: Simultaneous production of zinc and chlorine. Zinc '83, Proceedings $13^{\text {th }}$ Annual Hydrometallurgy Conference, Canadian Institute of Mining, Metallurgy and Petroleum, Montreal, 1-22.

Okhotskii, V. B., 2007. Formation of iron oxide dust in steel smelting. Steel Transl. 37 (12), 979-981. DOI:10.3103/S0967091207120017

Onnen, J. H., 1972. Wet scrubbers tackle pollution. Environ. Sci. Technol. 6 (12), 994-998. DOI:10.1021/es60071a007.

Orbaek, A., Barron, A. R., 2015. ICP-AES analysis of nanoparticles. OpenStax CNX. Mar 24, 2015 http://cnx.org/contents/fb3818e2-cbcb-4582-bb7c-3a467a716cc0@21.

Oustadakis, P., Tsakiridis, P. E., Katsiapi, A., Agatzini-Leonardou, S., 2010. Hydrometallurgical process for zinc recovery from electric arc furnace dust (EAFD). Part I: characterization and leaching by diluted sulphuric acid, J. Hazard. Mater. 179 (1-3), 1-7. DOI:10.1016/j.jhazmat.2010.01.059.

Peters, A. G. A., 2019. Zinc vapourisation from sludge wastes under thermal processing conditions - zinc enrichment in HIsarna flue dust. Thesis, MSc. Delft University of Technology.

Porter, F., 1991. Zinc Handbook: Properties, Processing, and Use in Design. International Lead Zinc Research Organization. ISBN: 0824783409.

Ray, S. K., Chattopadhyay, G., Ray, A. K., 1997. Evaluation of dust generated from basic 
oxygen furnace steel making. J. Air Waste Manag. Assoc. 47 (6), 716-721. DOI:10.1080/10473289.1997.10463929.

Rinker, F. G., 2001. Using the DRylron ${ }^{\mathrm{TM}}$ process to produce value-added iron units. Miner. Metall. Process. 18 (1), 45-48. DOI:10.1007/BF03402870.

Rose, J., Cortalezzi-Fidalgo, M. M., Moustier, S., Magnetto, C., Jones, C. D., Barron, A. R., Wiesner, M. R., Bottero, J.-Y., 2002. Synthesis and characterization of carboxylate-FeOOH nanoparticles (ferroxanes) and ferroxane-derived ceramics, Chem. Mater. 14 (2), 621-628. DOI:10.1021/cm010583r.

Salama, W., El Aref, M., Gaupp, R., 2015. Spectroscopic characterization of iron ores formed in different geological environments using FTIR, XPS, Mössbauer spectroscopy and thermoanalyses, Spectrochim. Acta - Part A Mol. Biomol. Spectrosc. 136 (Part C), 18161826. DOI:10.1016/j.saa.2014.10.090.

Sammut, M. L., Rose, J., Masion, A., Fiani, E., Depoux, M., Ziebel, A., Hazemann, J. L., Proux, O., Borschneck, D., Noack, Y., 2008. Determination of zinc speciation in basic oxygen furnace flying dust by chemical extractions and X-ray spectroscopy. Chemosphere 70 (11), 1945-1951. DOI:10.1016/j.chemosphere.2007.09.063.

Santos, J., Phillips, J., Dumesic, J. A., 1983. Metal-support interactions between iron and titania for catalysts prepared by thermal decomposition of iron pentacarbonyl and by impregnation. J. Catal. 81 (1), 147-167. DOI:10.1016/0021-9517(83)90154-9.

Schoukens, A. F. S., Shaw, F., Chemaly, E. C., 1993. The Enviroplas process for the treatment of steel-plant dusts. J. South. Afr. Inst. Min. Metall. 93 (1), 1-7.

Steffen, R., Lüngen, H.-B., 2004. State of the art technology of direct and smelting-reduction of iron ores. Metall. Res. Technol. 101 (3), 171-182. DOI:10.1051/metal:2004131

Stephenson, R. L., Smailer, R. M., 1999. Direct reduced iron: technology and economics of production and use. Iron \& Steel Society. London, UK. ISBN:1886362319.

Mager, K., Meurer, U., Wirling, K. 2003. Minimizing dioxin and furan emissions during zinc dust recycle by the Waelz process. JOM 55 (8), 20-25. DOI: https://doi.org/10.1007/s11837003-0099-6

Meijer, K., Zeilstra, C., Teerbuis, C., Ouwehand, M., van der Stel, J., 2013. Developments in 
Alternative Ironmaking. Trans Indian Inst Met 66, (5-6), 475-481. DOI: 10.1007/s12666013-0309-Z

Murao, A., Sawa, Y., Hiroha, H., Matsui, T., Ishiwata, N., Higuchi, T., Takeda, K., 2008. HiQIP, a new ironmaking process, Iron Steel Technol. 5 (3), 87-94. ISSN:1547-0423.

Sawa, Y., Yamamoto, T., Takeda, K., Itaya, H., 2001. New coal based process to produce high quality DRI for the EAF, ISIJ Int. 41, 17-21. DOI: 0.2355/isijinternational.41.Suppl_S17.

Seetharaman, S., 2013. Treatise on Process Metallurgy, Vol. 3: Industrial Processes, Part A, Ed. Seetharaman, S., McLean, A., Guthrie, R., Sridhar, S., Elsevier, Oxford.

Shawabkeh, R. A., 2014. Hydrometallurgical extraction of zinc from Jordanian electric arc furnace dust. Hydrometallurgy 104 (1), 61-65. DOI: 10.1016/j.hydromet.2010.04.014.

Singh, R., 2012. Applied Welding Engineering: Processes, Codes and Standards. Chapter 5: Production of Steel. Elsevier. DOI: 10.1016/B978-0-12-391916-8.00005-4.

Southwick, L. M., 2010. Still no simple solution to processing EAF dust. Steel Times Int., 4345. Available from: www.steeltimesint.com/contentimages/features/EAFdustMar10.pdf. Accessed 24 September 2019.

Steer, J., Griffiths, A., Heinrich, T., Thomas, A., Barnes, C., 2014. Correlation of BOS Process Variables with dust mass formation and zinc content. Ironmak. Steelmak. 41 (7), 554-560 DOI:10.1179/1743281213Y.0000000152

Sun, X. Hwang, J. Huang, X. The Microwave Processing of electric arc furnace dust. JOM 60, 35-39 (2008) DOI:10.1007/s11837-008-0132-x

Tsujino, R., Hirai, M., Ohno, T., Ishiwata, N., Inoshita, T., 1989. Mechanism of dust generation in a converter with minimum slag. ISIJ Int. 29 (4), 291-299. DOI:10.2355/isijinternational.29.291.

Turkdogan, E., Leake, L., 1959. Preliminary studies on the evolution of fumes from iron at high temperatures. J. Iron Steel Inst. 192, 162-170.

Vereš, J., Šepelák, V., Hredzák, S., 2015. Chemical, mineralogical and morphological characterisation of basic oxygen furnace dust. Miner. Process. Extr. Metall. 124 (1), 1-8. DOI: $10.1179 / 1743285514 Y .0000000069$.

Verwey, E. J., Haayman, P. W., Romeijn, F. C., 1947. Physical properties and cation 
arrangements of oxides with spinel structure, J. Chem. Phys. 15 (4), 181-187. DOI:10.1063/1.1746464.

Walburga Keglevich de Buzin, P. J., Heck, N, C, Vilela, A, C, F., 2017. EAF dust: An overview on the influences of physical, chemical and mineral features in its recycling and waste incorporation routes. Journal of Materials Research and Technology 6 (2), 194-202. DOI: 10.1016/j.jmrt.2016.10.002.

World Steel Association, World Steel in Figures 2017, 2017.

World Steel Association, Sustainable Steel - Indicators 2017 and the Future, 2017. Available from www.worldsteel.org. Accessed 8 May 2019.

Worrell, E., Price, L., Martin, N., 2001. Energy efficiency and carbon dioxide emissions reduction opportunities in the US iron and steel sector. Energy 26 (5), 513-536. DOI:10.1016/S0360-5442(01)00017-2.

Wu, X., Liu, Z., Liu, X. L., 2014. The effects of additives on the electrowinning of zinc from sulphate solutions with high fluoride concentration, Hydrometallurgy. 141, 31-35. DOI: 10.1016/j.hydromet.2013.09.007.

Zboril, R., Mashlan, M., Petridis, D., 2002. Iron(III) oxides from thermal processes-synthesis, structural and magnetic properties, Mössbauer spectroscopy characterization, and applications. Chem. Mater. 14 (3), 969-982. DOI:10.1021/cm0111074.

Zhang, Y. Y., Qi, Y. H., Zou, Z. S., Li, Y. G., 2013. Development prospect of rotary hearth furnace process in China. Adv. Mater. Res. 746, 533-538. DOI:10.4028/www.scientific.net/AMR.746.533.

Zunkel, D., 1996. What to do with your EAF Dust, Steel Times Int. 20 (3), 46-50. 